\title{
The Effects of Quantitative Easing on Bank Lending Behavior*
}

\author{
Alexander Rodnyansky \\ Princeton University
}

Olivier Darmouni

Columbia Business School

First Version: September 2, 2014

This Version: December 30, 2016

\begin{abstract}
Banks' exposure to large-scale asset purchases, as measured by the relative prevalence of mortgage-backed securities on their books, affects lending following unconventional monetary policy shocks. Using a difference-in-differences identification strategy, this paper finds strong effects of the first and third round of quantitative easing (QE1 and QE3) on credit. Highly affected commercial banks increase lending by 2 to $3 \%$ relative to their counterparts. QE2 had no significant impact, consistent with its exclusive focus on Treasuries sparsely held by banks. Overall, banks respond heterogeneously and the type of asset being targeted is central to QE.
\end{abstract}

${ }^{*}$ We would like to thank the editor, Philip Strahan, and an anonymous referee for highly valuable comments. Rodnyansky is extremely grateful to his advisers, Mark Aguiar, Markus Brunnermeier, Mikhail Golosov, Oleg Itskhoki, and Motohiro Yogo for their continual guidance and support. We also thank Saki Bigio, Maryam Farboodi, Valentin Haddad, Harrison Hong, Nobuhiro Kiyotaki, Atif Mian, Tomasz Piskorski, Richard Rogerson, Hyun Song Shin, David Sraer, Claudia Steinwender, Wei Xiong, our fellow Ph.D. students, as well as the participants of the Macro-Financial Modeling Winter 2016 meeting at NYU Stern, Columbia's macro lunch and Princeton's finance and macro workshops for extremely valuable advice. Rodnyansky gratefully acknowledges financial support from the Macro-Financial Modeling Group. Rodnyansky: Princeton University, Fisher Hall, Princeton, NJ 08544-1021 (a.rodnyansky@gmail.com); Darmouni: Columbia Business School, 216 Uris Hall, New York, NY 10027 (omd2109@columbia.edu). 


\section{Introduction}

What are the effects of unconventional monetary policy, and how does its transmission mechanism work? These questions began to attract ever more attention during the wake of the Great Recession and following a series of aggressive liquidity measures by the Fed. In a dramatic change of policy, the European Central Bank (ECB) lately also announced its own "expanded asset purchase program". Meanwhile, banks play a central role in the monetary system and in facilitating economic activity as shocks to the banking sector can have real effects by reducing firm borrowing and employment (ChodorowReich (2014b)). Motivated by these findings, this paper explores the impact of the three rounds of large-scale asset purchases (LSAPs), colloquially known as quantitative easing (QE), on commercial bank lending in the US.

The effectiveness of LSAPs has been a topic of vivid debate over the last couple of years. Most recently, when the Fed phased out of QE3, policy makers, commentators and analysts around the world were hoping to distill and summarize the policy's overall economic impact. ${ }^{1}$ The majority of assessments, whether positive or negative, tend to focus on some uniform macroeconomic effects, including a fall in long-term interest rates, changes in confidence and inflation expectations. However, assessing policy success is made difficult by the absence of a control group which would be unaffected by the policy at such macro levels. Proponents of QE usually praise the Fed for raising asset prices and lowering yields on US Treasuries or mortgage-backed securities (MBS). Overall levels of confidence are seen to have improved, leading to greater borrowing and spending decisions on behalf of consumers. The aggregate post-crisis recovery, it is argued, came about a lot more promptly than it would have done without QE. On

\footnotetext{
1Source: "Has quantitative easing worked in the US?", BBC, Oct. 30, 2014.
} 
the other side of the debate, skeptics see QE as having fueled asset bubbles, which led to a build-up of excessive risk-taking and encouraged investors to seek refuge in questionable investments as they increasingly chose to "reach for yield". Besides, critics have pointed to the last round of asset purchases as being inadequate and failing to raise inflation expectations. An ever improving state of the economy around 2013 was therefore seen as entirely unrelated to the Fed's last round of quantitative easing. ${ }^{2}$

This paper is the first to provide evidence on LSAPs stimulating lending by banks with considerable holdings of mortgage-backed securities on their books. Using a difference-in-differences identification strategy, banks with relatively larger holdings of MBS are shown to have expanded lending after the first and third rounds of quantitative easing (QE1 and QE3). On the other hand, QE2 had no significant influence on credit provision as it focused exclusively on Treasuries that are sparsely held by banks. Contrary to conventional wisdom, the novel takeaways consist in recognizing large heterogeneous effects of QE across lending institutions and the targeted asset's centrality for the transmission mechanism of unconventional monetary policy.

The paper starts out by empirically documenting commercial banks' exposure to the Fed's large-scale asset purchases of mortgage-backed securities. Aggregating individual bank data to the bank holding company (BHC) level from 2008Q1 until 2014Q1, each institution's sensitivity towards QE is captured by the MBS-to-Assets ratio. In order to minimize endogeneity, and even though banks' security holdings are remarkably sticky over time, banks are classified according to their MBS holdings in 2008Q1, which is more than a half-year before the first wave of QE. This measure of exposure is characterized by substantial cross-sectional variation across banks: while the median fraction of banks'

\footnotetext{
2Source: "The 2\% Mystery: Why Has QE3 Been Such a Bust?", The Atlantic, Feb 22, 2013.
} 
assets held as agency MBS is $5 \%$, this number stands at $12 \%$ for the upper quartile.

Exploiting this cross-sectional variation to estimate the effect of quantitative easing via a standard difference-in-differences approach, we find strong and significant effects of QE1 and QE3 on the lending behavior of bank holding companies with a large share of MBS relative to their counterparts. The former group increases levels of lending by about 3\% after QE1 compared to banks with little exposure, and about $2 \%$ after QE3. In contrast, QE2 focused on Treasuries and exerted virtually no differential impact on lending institutions.

Accounting for the legal restrictions governing asset purchases by the Fed as well as its declared objectives of providing support to housing markets and fostering improved financial conditions more generally, the cross-sectional variation of the MBS-to-Assets ratio across banks was orthogonal to the evolution of each institution's pre-intervention lending rates. And while the allocation of relative MBS holdings is unlikely to be random but instead reflects diverse securitization activity and specialization in real-estate lending (as confirmed by Erel et al. (2013)), a serious effort is made to address this issue both via conditioning on a number of relevant differences among banks as well as through a matching approach to adjust the data before carrying out additional parametric analysis. With the aid of non-parametric pre-processing using standard probit models, the latter matching methodology permits to weaken the link between a bank's treatment status and other covariates. This effectively restricts attention to a select group of matched treatment and control institutions, with evidence from this sample being supportive of a parallel trends assumptions in lending outcomes for diverse groups of banks before the onset of QE. In other words, while the levels of lending are markedly different across treated and untreated banks throughout all time periods, there is no reason for the gap 
between both groups to have widened in the absence of the Fed's interventions.

The paper also considers a myriad of robustness checks to allow for the possibility of time-varying heterogeneity across differentially exposed groups of banks. Extant research documents a "narrow channel" of QE, solely affecting the prices of each particular asset being purchased and thereby lends additional support to the main identification strategy. ${ }^{3}$ Next, a placebo analysis covering the post-2001 recession boom period finds no significant differences in lending outcomes for banks with heterogeneous MBS exposure. Finally, to fully account for borrower-level shocks that could potentially confound any bank-level findings, the Call Reports are hand-matched with Dealscan loan-level data on commercial and industrial loans to estimate the effect of QE including borrower fixed effects. This setup allows to discern whether banks with larger holdings of MBS are more likely to lend to the same firm relative to other institutions and confirms the original bank-level findings.

We carefully explore two relevant channels by which large-scale asset purchases could exert influence on banks' proclivity to lend via a balance sheet improvement. The first channel is the "net worth channel": when asset purchases have a large impact on security prices, the policy increases the mark-to-market value of bank security holdings and in turn raises bank net worth, a mechanism recently labeled as "stealth recapitalization" by Brunnermeier and Sannikov (2014). We find this net worth channel to be at play during QE1, but not during the following waves of QE, consistent with previously established results about later rounds of QE having a smaller impact on MBS prices. In line with this view, we find that treated banks expanded assets and experienced gains

\footnotetext{
${ }^{3}$ Krishnamurthy and Vissing-Jorgensen (2013) argue that QE does not work via broad channels affecting the term premium on all long term bonds, but instead decreases mortgage interest rate spreads whenever targeted at MBS.
} 
on their security holdings only after QE1. On the other hand, QE3 appeared to have worked through a "liquidity channel": as MBS became more liquid, banks could swap them for reserves and expand their lending. Additional illiquidity coming from more lending is mitigated by extra liquidity on the rest of the asset side. Our results reveal that there are multiple channels by which this supplementary liquidity created by QE can be used within the banking sector.

\subsection{Relation to the Literature}

This paper is primarily related to the literature on the bank lending channel of monetary policy transmission (Kashyap and Stein (1994)). Seeking to find evidence that monetary policy affects the economy via credit supply, the bank lending channel posits a failure of the Modigliani-Miller theorem for banks. In line with these arguments, Kashyap and Stein (1995) show that monetary tightening reduces lending by relatively small banks. Analogously, Campello (2002) provide evidence that contractionary monetary policy reduces the amount of loans made by banks that are unrelated to a large banking group. Kashyap and Stein (2000) elucidate the same mechanisms for banks that hold fewer liquid assets, while Kishan and Opiela (2000), Gambacorta and Mistrulli (2004) carry out the analysis for banks with higher leverage ratios. More recent work investigates a risktaking channel, where reductions in policy rates cause financial institutions to take on larger risks and result in lower risk premia (Adrian and Shin (2010a), Borio and Zhu (2012)). Focusing on the income gap, a measure of banks' cash flow exposure to interest rate risk, Landier et al. (2015) document its pivotal role for the lending behavior of banks following monetary policy shocks.

Another proximate branch of literature concerns the liability structure of banks dur- 
ing periods of liquidity shocks. Dagher and Kazimov (2015) use loan-level data to show that banks end up curtailing their lending by more if they are heavily reliant on wholesale funding during crises. Ivashina and Scharfstein (2010) demonstrate that banks cut less of their lending during the 2008 crisis if they had better access to deposit financing and were less dependant on short-term debt. The broader work studying the impact of liquidity shocks on credit supply includes Puri et al. (2011), Paravisini (2008), Peek and Rosengren (2000), and Cornett et al. (2011). A recent extension of the Khwaja and Mian (2008) methodology in loan-level regressions to isolate credit supply devised by Jiménez et al. (2014) to identify aggregate firm-level effects through credit shocks is also taken up in the present study.

This research is also related to a strand of theoretical work emphasising the sharply non-linear effects of financial sector capital on risk premia and lending (He and Krishnamurthy (2013), Brunnermeier and Sannikov (2014)). In these models, large contractions in financial sector capital lead to binding borrowing constraints or adverse feedback loops. In a fire sale, the pressure to delever decreases mark-to-market prices of assets held at other institutions, leading to further deleveraging (Shleifer and Vishny (2011)). The focus on liquidity management issues interacted with monetary policy shocks and lending choices is closely linked to the agenda of Bianchi and Bigio (2014).

Part of the mechanism uncovered in this paper is the empirical analogue of redistributive monetary policy, as first introduced by Brunnermeier and Sannikov (2015). In their model, monetary policy impacts the real economy by affecting the value of assets held by agents on their books. For instance, raising the price of a long-term security effectively improves the balance sheets of agents who hold this asset and relaxes financial constraints. In other words, such policy is equivalent to a stealth recapitalisation of these 
agents. The key aspect is that not all agents in this economy are affected in the same way: heterogeneity in asset holdings matters for aggregate outcomes and policy makers should choose carefully which asset to buy instead of simply focusing on quantity, an insight which the present study is first to uncover empirically.

This mechanism is akin to the net-worth channel developed in Bernanke and Gertler (1989), Kiyotaki and Moore (1997), and Bernanke et al. (1999). Unconventional monetary policy raises the prices of MBS held as assets and leads to an improvement in the mark-to-market value of bank equity. Assuming that commercial banks target constant leverage ratios (Adrian and Shin (2010b)), these changes induce banks to expand their lending and take on additional debt.

The nascent literature studying the effects of LSAPs is also very much related to this paper. The high-frequency event study by Chodorow-Reich (2014a) suggests that the Fed's unconventional monetary policy actions had a strong positive impact on banks and life insurance companies by raising the value of their legacy assets in 2008. Krishnamurthy and Vissing-Jorgensen (2013) examine the influence of quantitative easing on asset prices and interest rate spreads, Morais et al. (2015) provide some first evidence on the international dimensions of QE, documenting credit supply spillovers from US and European banks to Mexico, a contemporaneous paper by Di Maggio et al. (2016) looks at unconventional monetary policy in relation to re-financing and consumption choices, while another very recent paper by Chakraborty et al. (2016) explores the impact of MBS purchases on the industrial organization of loan origination across regions in the US. Our focus on the total amount of credit is complementary to other papers looking at loan costs and re-financing (Agarwal et al. (2015), Beraja et al. (2016)). Finally, this article is linked to previous work on the real effects of credit market disruptions, especially in 
the aftermath of the 2008 crisis (Chodorow-Reich (2014b) and Greenstone et al. (2014)).

The structure of this paper is as follows. Section 2. begins with a chronology of the events and institutional features of LSAPs. Section 3. describes the main data sources and identification strategy of the paper. Section 4. presents the results for all three rounds of QE. Finally, section 5. sheds light on the central mechanisms driving the results, and section 6 . concludes.

\section{Background of LSAPs}

The initial wave of large-scale asset purchases (QE1) began on November 25, 2008 when the FOMC announced a program to purchase agency mortgage-backed securities (MBS) with the stated intentions of providing support to mortgage lending and housing markets as well as fostering improved conditions in financial markets more generally. The purchase phase was completed on March 31, 2010 after the Fed accumulated \$1.25 trillion in MBS, \$175 billion in federal agency debt (issued by Fannie Mae, Freddie Mac and Ginnie Mae) and $\$ 300$ billion in long-term Treasury securities. At that point, the Fed's market share of agency MBS had reached approximately 25\%. While the purchase of $\$ 300$ billion in long-term Treasuries was meant to exert downward pressure on interest rates in general, the joint purchase of $\$ 1.425$ trillion of MBS and agency debt was aimed at increasing credit availability in private markets, resuscitating mortgage lending and supporting the housing market.

In mid-2010, numerous concerns about a deflationary spiral led to serious fears of a lost decade of economic growth, similar to Japan's experience during the 1990s. To avert deflation, the Federal Open Market Committee (FOMC) introduced a second round of 
LSAPs (QE2), entailing the total purchase of $\$ 778$ billion in long-term Treasury securities, which included $\$ 600$ billion in announced program purchases and $\$ 178$ billion as reinvestment of principal payments from the Fed's agency debt and MBS holdings. This second round of quantitative easing lasted from November 3, 2010 until June 30, 2011 and proceeded at a pace of $\$ 75$ billion per month.

With the onset of Europe's sovereign debt crisis threatening to further destabilize the US economy, the FOMC turned to its maturity extension program, known as Operation Twist. This involved the sale of short-term Treasury securities and an equal purchase of long-term Treasury securities to exert downward pressure on long-term interest rates while maintaining the same amount of securities on the Fed balance sheet. Operation Twist was started in September 2011 and extended in June 2012 to continue through the end of 2012. Overall, the FOMC purchased, sold and redeemed $\$ 667$ billion in Treasury securities through this program, dispensing all holdings of short-term securities with a maturity of one year or less.

Finally, on September 13, 2012 the FOMC began a largely unanticipated third round of quantitative easing (QE3). ${ }^{4}$ The purchases initially involved $\$ 40$ billion in agency MBS per month. However, after Operation Twist ended in December 2012, the FOMC added $\$ 45$ billion in long-term Treasury securities to the monthly purchase. And while at its December 2013 meeting, the FOMC reduced the monthly asset purchases for the first time, dropping the total amount to $\$ 75$ billion from $\$ 85$ billion, ${ }^{5}$ the QE3 program continued as state-contingent and open-ended initiative until October 29, 2014 when it

\footnotetext{
${ }^{4}$ The extent of the Fed's push towards recovery was a surprise to traders, prompting a rally in stocks and commodities. In particular, the Wall Street Index rose by $1.6 \%$ within two hours of the news, along with huge gains in Asian and European markets. For more: "QE3: Reactions to the Fed's big stimulus move", The Washington Post, September 13, 2012.

${ }^{5}$ This $\$ 10$ billion reduction consisted of an equal $\$ 5$ billion decline for both MBS and US Treasury security purchases.
} 
was formally discontinued. By the end of all three QE rounds, the Fed had accumulated $\$ 1.75$ trillion in MBS, representing around 30\% of the entire agency MBS market.

For the analysis in subsequent sections, it is important to highlight some institutional features of the Fed's LSAPs throughout this period. Agency MBS are generally demarcated by different coupons, corresponding to the interest rate on the underlying mortgage loans. More than $90 \%$ of agency MBS trading volume occurs in the To-BeAnnounced (TBA) forward market. ${ }^{6}$ And while the degree of integration in the agency MBS market is quite high, the Fed's purchases were primarily targeted at mortgagebacked securities with coupons near those of new mortgage loan originations, often called current-coupon or production-coupon MBS. These assets have greater liquidity and are closely tied to primary mortgage rates. Meanwhile, the TBA market is the most liquid, and hence the most important secondary market for mortgage loans. Market participants that benefit from TBA trading are primarily mortgage bankers, commercial banks, and thrift institutions that originate residential mortgages and sell them into the secondary mortgage market in securitized form. According to the rules of the Federal Reserve Act, only fixed-rate agency MBS guaranteed by Fannie Mae, Freddie Mac and Ginnie Mae were eligible assets for purchase, including the 30-year and 15-year securities of these issuers. The New York Fed's primary dealers were entitled to transact in agency MBS directly with the Federal Reserve, and they were expected to submit bids or offers for themselves as well as for their customers.

\footnotetext{
${ }^{6}$ In a TBA trade, the buyer obtains a contract for delivery of securitized mortgage loans at some date in the future. As part of a unique feature of such contracts, the buyer is left in the dark about the actual identity of the securitized mortgage loans to be delivered. Instead, participants agree on general parameters, such as the issuer, maturity, or coupon, and the buyer discovers the actual parameters of the loan 48 hours prior to the settlement of the forward contract.
} 


\section{Data and Empirical Strategy}

\subsection{Data Construction}

This paper mainly relies on two datasets: i) the Consolidated Reports of Condition and Income (Call Reports), formally known as the FFIEC 031 and FFIEC 041 regulatory filings, which must be submitted each quarter by all commercial banks with insured deposits and from which all main variables in the analysis are sourced, and ii) the Dealscan syndicated loan database, which contains the borrowing history of both public and private firms that have accessed the syndicated loan market. The Call Reports include detailed information on the composition of banks' income statements, balance sheets, and off-balance sheet items. The time period under consideration in this study spans the main period of LSAPs, from 2008Q1 up until 2014Q1.

In line with most of the empirical literature based on the Call Reports, the raw data are adjusted to account for the fact that many banks are part of multibank holding companies. Hence individual bank data are aggregated to comprise holding-company level financial information. That is, any given bank in the sample is really a holding company which does not include any of its non-bank subsidiaries, as these are excluded from the Call Reports. ${ }^{7}$ An effort is made to minimize the number of excluded banks and thereby avoid any sample-selection biases. Following Kashyap et al. (2002), no direct conditioning on whether banks engage in mergers or acquisitions is carried out in the regression models below, even though the continuous representation of separate bank entities over the whole sample period is a binding restriction in the fixed-effects specifications in sections 4.1. and 4.2.. In other words, all tests are carried out with a

\footnotetext{
${ }^{7}$ It is important to point out that the results are largely unaffected by working with the disaggregated data at the individual bank level.
} 
balanced sample of bank holding companies. ${ }^{8}$

The loan market data come from the Thomson Reuters Dealscan database, which collects loan-level information on syndicated loans from Securities and Exchange Commission (SEC) filings, company statements, media reports, and attempts to process the universe of such loans. ${ }^{9}$ The data include the identities of the borrower and lenders present at origination, the terms of the loan, the maturity, size, interest rate, type, and purpose of the loan (for example, working capital, or leveraged buyout). For the tasks in this paper, the Dealscan database is also hand-matched to the Call Reports for the 95 largest bank holding companies in the loan-level analysis of QE in section 4.3..

A set of dependent, independent and control variables is constructed for all included bank observations. The definitions of all these variables are listed precisely in Appendix A. Summary statistics are reported in Tables 2 and 3.

\subsection{Empirical Strategy}

In light of the major LSAP events described in section 2., this paper exploits disparities in the level of exposure towards the Fed's interventions by grouping banks according to the relative amount of mortgage-backed securities on their balance sheets. For identification, this difference-in-differences (DiD) methodology relies upon the interaction of aggregate endogenous variation in MBS prices or purchases with sufficient cross-sectional variation

\footnotetext{
${ }^{8}$ As an alternative procedure to control for any possible M\&A activity, restricting the entire sample to banks that have quarterly total asset growth of no more than $10 \%$ for any given banking organization yields very similar baseline results.

${ }^{9}$ Public companies are obliged to report any new bank loan to the SEC via 8-K filings, or as an attachment to their quarterly or annual reports. The public ranking of lender activity in the syndicated loan market assembled by Thomson Reuters on the basis of Dealscan is thought to provide banks with additional incentives to report loans, which Dealscan might otherwise have missed. Loans with a single lead arranger and zero participants are usually somewhat larger than other loans in the dataset.
} 
among banks in their MBS holdings. Figure 1 plots the price series of Fannie 30-year 3\% coupon MBS in Panel (a), and the prices of Fannie 30-year 5\% coupon MBS in Panel (b). [Insert Figure 1 here]

The former series is representative of the targeted securities during QE3, when interest rates were already much lower than in 2008, while the latter graph is indicative of the types of assets being purchased during the first phase of LSAPs. One immediate takeaway from Panel (b) is the relatively large and persistent price effect of QE1. In line with previous findings by Krishnamurthy and Vissing-Jorgensen (2013), the Fed programs seemed to operate via a "narrow channel", with no clear MBS price impact of QE2. The response of prices to QE3 is visible but a lot more modest than the one observed after QE1, both in terms of magnitude and life span, which is not surprising given the substantially slower pace of MBS purchases during QE3.

It should be pointed out, however, that commercial banks held approximately $26 \%-30 \%$ of total agency MBS outstanding over the period from September 2013 until December 2014, ${ }^{10}$ and hence one should still expect a sizeable liquidity effect from the Fed's LSAPs, as will be confirmed below when looking at the effects on realized gains on available-for-sale securities for relatively exposed commercial banks.

The cross-sectional variation in MBS holdings across banks, defined by their MBSto-Assets ratio, is also large during all periods under consideration. From the summary statistics reported in Table 2, one can see that the MBS-to-Assets ratio has a standard deviation of 0.10 and mean value of $0.08^{11}$. Moreover, there are even some institutions for which this variable is either zero or close to 0.83 . Figure 2 displays a histogram for

\footnotetext{
${ }^{10}$ Source: Federal Reserve, Flow of Funds.

${ }^{11}$ An alternative is to sort banks according to their MBS-to-Securities ratio (standard deviation of 0.31 and mean of 0.35 ). Unreported specifications use this alternative definition for robustness.
} 
the entire distribution of MBS-to-Assets and MBS-to-Securities in the sample during the cutoff period before QE1, which is in 2008Q1.

[Insert Table 1, Table 2 and Figure 2 here]

In most baseline specifications, the impact of quantitative easing is assessed via difference-in-differences regressions that define banks from the lowest $25 \%$ of the MBSto-Assets distribution as the control group (C) and institutions among the highest $25 \%$ of the sample as the treatment group (T). We also report results using the MBS-to-Assets ratio as a continuous variable, which allows for an analysis of the entire sample of banks. Moreover, as displayed in the transition matrices in Table 1, banks are extremely rigid in their relative MBS-to-Assets holdings over time, with very little movement in the re-calculated treatment assignments from quarter to quarter. This alleviates the concern that banks anticipate or strategically respond to QE by adjusting their holding of mortgage-backed securities over time.

Nevertheless, banks with higher than median MBS holdings are distinct along a number of important observable characteristics. Table 4 tests whether treated banks are in fact systematically different from their counterparts. As a fraction of their assets, banks with a relatively high MBS-to-Assets ratio as of 2008Q1 are similar to the control group in terms of lending over the entire time period. However, treated banks are usually a lot bigger, hold more securities, and are slightly less profitable on average. This implies that all regressions should control for the main disparities, such as size and other balance sheet items pertinent to bank lending decisions.

\section{[Insert Table 4 here]}

To reduce potential biases in estimating the causal effects stemming from the endogenous determination of MBS holdings among bank holding companies themselves, 
all baseline specifications will use a standard propensity score matching approach. At first, a probit model is estimated to predict a bank's treatment status on the basis of major bank-level characteristics used in the pooled regressions before the QE interventions in 2008 Q1. Next, the predicted values from this probit regression (propensity scores) are employed to construct a nearest-neighbor matched sample of banks. While matching each high MBS-holding institution to a control bank with replacement, this approach effectively discards untreated observations that end up being too different based on observables from the treatment group. ${ }^{12}$

\section{[Insert Table 5 here]}

The following test is conducted to assess the quality of the matching procedure. In particular, the probit model is re-estimated on the matched sample of banks and the results are reported in Table 5. Compared to the pre-match probit regression that was used to perform a nearest-neighbor propensity score matching, and for which the estimates are presented in column (1), the magnitude of all probit regression coefficients declines substantially using the post-match model in column (2). In fact, none of the main dimensions of heterogeneity continue to play any role in explaining the treatment status across banks, whereas both size and profitability were statistically significant in the pre-match sample before. Furthermore, the $\chi^{2}$ test for overall model fit shows that one cannot reject the null hypothesis that all coefficient estimates are zero: the p-value equals 0.51 in column (2). Thus, the matching process removes meaningful differences

\footnotetext{
${ }^{12}$ Since certain institutions end up being matched with several treated banks more than once, the second step entails retaining the frequency weights from the above matching procedure for each undiscarded control bank. In order to have a sample of banks consistent across all specifications, control and treatment groups are defined according to median MBS-to-Assets holding in the matching procedure. It should be pointed out that using the whole unmatched sample of banks leaves all baseline regressions and robustness test largely unchanged in terms of the magnitude and statistical significance of our main findings.
} 
along observable dimensions between the two groups of banks.

[Insert Figure 3 here]

In an initial attempt to eye-ball the main data and outcome variables, Figure 3 plots the Federal Reserve Holdings of Treasury Notes (long-dashed green) and MortgageBacked Securities (dashed blue) from 2008Q1 until 2014Q1, all measured on the right vertical axis in billions of US dollars. The figure also shows the average lending-toassets ratios for treated banks in the upper quartile of MBS-to-Assets holdings (T group, in solid black) versus the lower quartile ( $C$ group, in dashed gray). These lending ratios are measured on the left vertical axis. The vertical lines and shaded areas mark the QE1, QE2 and QE3 periods.

\section{Results}

\subsection{Pooled regressions}

Yet even though Figure 3 contributes some preliminary evidence in favor of a positive liquidity shock stemming from the Fed's interventions, as the gaps in lending-to-assets ratios seem to narrow around QE1 and QE3, the presence of a lending channel cannot be taken for granted as banks with higher fractions of MBS holdings might differ systematically from their peers. For instance, banks with a higher exposure towards LSAPs may be lending to firms that experience faster credit demand growth due to improvements in their borrower health around the same time period. If this were true, the bank-level analysis would be spuriously driven by credit demand shocks and the results would be misattributed to the Fed's QE policies. To address these concerns, section 4.3. devotes 
attention to C\&I loan issuance data from Dealscan, implementing the Khwaja and Mian (2008) (KM) within-firm estimator to absorb firm fundamental shocks that proxy for a company's level of credit demand.

The initial regression framework to gauge the causal effects of QE consists of looking at average lending outcomes following each of the QE waves. The following pooled model is estimated: ${ }^{13}$

$$
\log \left(Y_{i, t}\right)=\alpha_{i}+\gamma^{\prime} \mathbf{Q E}_{t}+\delta^{\prime}\left(\text { Treat }_{i} \cdot \mathbf{Q E}_{t}\right)+\theta^{\prime} X_{i, t}+\lambda^{\prime} X_{i, t} \cdot \mathbf{Q E}_{t}+v_{i, t}
$$

where $Y_{i, t}$ is the level of either total, real estate, or C\&I lending, $\alpha_{i}$ is a bank fixed effect, Treat $_{i}$ is an indicator variable equal to 1 whenever a bank belongs to the treatment group as defined by the upper quartile and 0 if the institution belongs to the lower quartile of the MBS-to-Assets distribution prior to $Q E 1, Q_{t}=\left\{Q E_{1 t}, Q E_{2 t}, Q E_{3 t}\right\}$ is a set of indicator variables which become equal to 1 after the introduction of each QE episode, and Treat $_{i} \cdot \mathbf{Q E}_{t}$ is an interaction term between the QE dummies and a bank's treatment status. Following the literature on bank lending (e.g. Kashyap and Stein (2000)), the matrix of controls, $X_{i, t}$, includes bank size, equity normalized by total assets, return on assets (ROA) as a benchmark for profitability, and, in order to control for maturity mismatch, we also include the duration gap measure introduced by English et al. (2014) ${ }^{14}$. As a further robustness check on the identification strategy, all control variables are interacted

\footnotetext{
${ }^{13}$ In an earlier version of the paper, each QE round was considered in separate difference-in-differences model around the respective cutoff dates. The result are even stronger than the ones using the pooled specification. We use the latter for ease of exposition and magnitude comparisons across all QE waves.

${ }^{14}$ This paper uses Call Report data to construct a new, more refined measure of the mismatch between the repricing time or maturity of assets and liabilities at the individual bank level. While most of the literature has considered the share of assets and liabilities that mature or reprice within a year, the considerably more granular measure used in this paper constructs a weighted average of maturity for multiple categories of assets and liabilities and defines the maturity/repricing gap as the difference between the two. For more details, see English et al. (2014)
} 
with the $\mathbf{Q E}_{t}$ indicators to allow for possible heterogeneous responses to the intervention by bank holding companies of different nature. All standard errors are clustered at the bank level to allow for serial correlation across time.

[Insert Table 6 here]

The key parameters of interest are the elements of $\delta$ as they capture the difference in lending outcomes between banks with relatively high and low mortgage-backed security (MBS) portfolios after each of the QE shock. In other words, $\delta$ measures the treatment effect of each wave. Table 6 reports the results after estimating equation 1 for annual lending from 2008 to 2014. The first two columns consider the effect on total lending. Column (1) defines treatment and controls as the top and bottom quartile of the MBSto-Assets holding distribution in 2008Q1, while column (2) uses the continuous MBSto-Assets measure also before QE1. ${ }^{15}$ Across all specifications, we find a positive and robustly statistically significant effect of both QE1 and QE3. The last four columns reveal that the effect is primarily driven by an expansion in real estate lending (which is $55 \%$ of all loans), while corporate lending increases somewhat less strongly.

With the natural logarithm of lending as the dependent variable, these estimates suggest QE1 boosted lending of treated banks by about 3\% relative to the control group. The estimated effect of QE3 is about $2 \%$, although, as indicated by the $p$-value in the last row of Table 6, the difference between both coefficients is not always statistically significant. The effect of QE2 is estimated to be zero. ${ }^{16}$ The following "back-of-theenvelope" calculation can give a sense of the magnitude of the effects. For instance, as

\footnotetext{
${ }^{15}$ In non-parametric versions of the model, linearity seems to be a reasonable approximation. Also, the continuous measure has the additional benefit of using all observations in the sample.

${ }^{16}$ The results are unaffected by replacing the dependent variable to be the logarithm of lending-toassets, with assets held fixed prior to the introduction of QE. In other words, the impact of QE is large and significant because treated banks see their lending expand rather than assets contract.
} 
QE3 was introduced total lending by the treated banks in 2012Q2 was about $\$ 3.4$ trillion, and if one is willing to assume that the control group was completely unaffected by the policy, then the aggregate increase in bank lending would constitute about $\$ 100$ billion. ${ }^{17}$

US Treasuries are in general a much smaller component of commercial banks' balance sheets than mortgage-backed securities. One can see in Table 2 that the median level of Treasuries as a fraction of total securities is zero, while the median value of MBS as a share of securities is $32 \%$. Moreover, the upper quartile of the MBS-to-Securities distribution is $60 \%$, whereas it is still zero for the ratio of Treasuries-to-Securities. Given this importance of MBS relative to Treasuries, one should expect QE2 to have exerted a smaller influence on bank lending after all.

These findings provide evidence of the importance of the type of assets being purchased as part of any unconventional monetary policy intervention, as opposed to simply quantities. Since numerous commercial banks were heavily exposed to agency MBS, positive liquidity and price shocks to these particular assets led to much greater balancesheet improvements than any intervention targeted at relatively sparsely held securities. In times when QE becomes a more frequent phenomenon around the world, these results should help in guiding policy makers' decisions by revealing that certain financial agents would be more affected by LSAPs depending on the choice of asset.

\subsection{Timing of the effects}

To be plausibly driven by QE, all of the effects documented thus far need to have occurred after the policy introduction and not before. Indeed, the results might be driven

\footnotetext{
${ }^{17}$ It should be noted, however, that this number represents an upper bound for the aggregate effect of QE3 on lending as control banks are likely to have reduced their lending to some extent while treated banks expanded their lending.
} 
by some pre-existing trend in the data, with treated banks having begun to expand their lending relative to the control group prior to the introduction of QE. In order to lend additional support to the causal interpretation of the findings, the next series of tests relies upon using repeated observations for the same bank over time. As noted before, a balanced panel of banks is considered as a way to avoid possible M\&A activity and reduce outliers.

We estimate a fixed-effects regression using the matched sample of banks. In the spirit of Granger (1969), the following specification is estimated in order to see whether causes happen before consequences and not the other way around:

$$
\begin{gathered}
\log \left(Y_{i t}\right)=\alpha_{i}+\sum_{t} \gamma_{t} \mathbf{D}_{t}+\sum_{t} \delta_{t}\left(\mathbf{D}_{t} \cdot \text { Treat }_{i}\right)+X_{i t}^{\prime} \theta+\sum_{t} \psi_{t}\left(\mathbf{D}_{t} \cdot X_{i t}\right)+\epsilon_{i t} \\
\forall i, \forall t \in\{2008 Q 2, \ldots, 2014 Q 1\} \backslash\{2008 Q 1\}
\end{gathered}
$$

Here, as above, $Y_{i t}$ is the lending outcome, $\alpha_{i}$ are bank holding company fixed effects, Treat $_{i}$ is an indicator variable equal to 1 if a bank belongs to the upper quartile of the MBS-to-Assets distribution and 0 whenever an institution is assigned to the lower quartile, $\mathbf{D}_{t}$ is an indicator for the time period (quarter), with 2008Q1 taken as the omitted category, $\left(\mathbf{D}_{t} \cdot\right.$ Treat $\left._{i}\right)$ represents an interaction term between the time indicators and a bank's MBS treatment status, and $X_{i t}$ is a matrix of control variables that includes bank size, equity normalized by total assets, a measure of maturity mismatch and return on assets (ROA) as a benchmark for profitability. All standard errors are clustered at the bank-level to allow for serial correlation across time.

The main parameters of interest are $\delta_{t}$ since they capture the difference between banks with relatively high and low mortgage-backed security holdings over time. The 
estimated model includes one observation each quarter per bank.

[Insert Figure 4 here]

Figure 4 plots the key estimated parameters of interest, $\widehat{\delta}_{t}$, with $95 \%$ confidence intervals around them. As would be consistent with a differential impact of LSAPs, the estimates show no robust differences between the treated and control banks in the quarters prior to the phasing in of QE1, and increasing effects on lending after adoption. The three QE periods are demarcated with dashed lines: QE1 and QE3 have a positive effect on lending given out by treated banks, while the middle period coinciding with QE2 displays no such influence. The evidence for real estate lending is particularly clean, showing widening differences between both groups of banks during and shortly after QE1, whereas the estimates for C\&I loans are insignificant and add some noise to the total lending graph in Panel (a). Overall, though, even if the gaps in total lending between treated and control banks oscillate a little after the end of QE1 and before start of QE3, these differences widen permanently at the time of MBS purchases and thereby reinforce the causal interpretation of the results from section 4.1 ..

\section{[Insert Figure 5 here]}

In an effort to better understand the effects of $\mathrm{QE}$, we next investigate whether small and large banks vary in their lending sensitivity with respect to unconventional monetary policy. Banks above the median of the assets distribution as of $2008 Q 1$ are coded as "large" while institutions below this threshold are considered separately as "small". The matching procedure is applied and the treatment allocation by quartiles is re-defined within each of these balanced sub-panels. The corresponding $\widehat{\delta}_{t}$ parameter plots of equation 2 for each group are displayed in Panels (a)-(c) of Figure 5.

The results for total lending for the small group are sizeable, statistically significant 
and confirm the causal interpretation of QE through their timing. The effects on real estate lending are similar, while C\&I loans are remain largely unresponsive. These patterns are consistent with the notion that small banks are more likely to benefit from the balance sheet improvements due to $\mathrm{QE}$, and reinforce our previous findings.

\subsection{Loan issuance}

This section addresses the issue of potential confounding demand-side factors that could be driving the results. The analytical framework employs the Khwaja and Mian (2008) (KM) technique, which has by now been widely applied in many papers to identify credit supply effects at the loan (bank-firm) level.

The sample consists of American non-financial firms that receive a loan to finance the firm's operations. ${ }^{18}$ To quantify the effect of the QE shock on firm borrowing, the methodology compares the last loan received by the firm before QE with the first loan received after QE. ${ }^{19}$ Dealscan has information on the total dollar amount of each loan for the entire syndicate of lenders, and the size of the loan of each separate lender is recovered via their loan shares. These loan shares are computed following the imputation method introduced in Chodorow-Reich (2014b). For robustness, the effect of QE on a "loan renewal" dummy, equal to 1 if the firm borrows again from a given lender after $\mathrm{QE}$, is also studied. This second measure of lending is robust to potential measurement errors in the dollar amount of lending.

\footnotetext{
${ }^{18}$ The purpose of the loan is recorded in Dealscan as either "working capital" or "corporate purposes".

${ }^{19}$ For QE1, the pre-QE period spans September 2005 to November 2008, and the post-QE1 period covers December 2008 to January 2010. For QE2, the pre-QE2 timeframe spans September 2008 to November 2010, and the post-QE2 period goes from December 2010 to January 2012. For QE3, the pre-QE window spans July 2010 to September 2012, while the post-QE period encompasses October 2012 to December 2013. Choosing the two closest loans in each interval minimizes having overlapping intervals, a necessity to achieve sufficient sample size.
} 
Starting with the bank-firm level analysis and focusing on the sample of borrowers that obtained a loan in the pre-QE period can help address whether unobserved characteristics of borrowers, especially demand shocks, correlate at the lender level. The exercise begins by asking whether banks that increased overall C\&I lending by more than other lenders also experienced a relative increase in their lending to the same firm when compared with other banks. Tables 7 implements this test for each wave of QE by regressing the change in lending in a firm-bank pair on the $\mathrm{QE}$ exposure indicator and a full set of firm fixed-effect that absorb any borrower characteristics which could influence loan outcomes. The inclusion of borrower fixed-effects necessitates every borrower to have more than one lender. As a result, the sample includes one observation for each lead lender and participant in the pre-QE syndicate. The following model is estimated:

$$
\log \left(1+L_{\text {post-QE }}^{b, f}\right)-\log \left(L_{\text {pre-QE }}^{b, f}\right)=\eta_{f}+\rho \cdot \text { Treat }_{b}+v_{b, f}
$$

where the dependent variable is the log change in the dollar value of lending by a syndicate member from the pre- to the post-QE period. $L_{t}^{b, f}$ is the dollar value of a loan multiplied by bank $b^{\prime}$ s imputed share of the loan to firm $f$ in period $t \in\{$ pre-QE, post-QE\}, $\eta_{f}$ are firm fixed-effects, Treat $_{b}$ denotes the MBS treatment indicator, and $v_{b, f}$ is an idiosyncratic error term.

\section{[Insert Table 7 here]}

Across multiple specifications, we find similar results to the previous section. The treatment effect of QE1 and QE3 is positive and significant, while QE2 has virtually no effect. For instance, looking at column (1) of Table 7, one can see that while overall C\&I lending contracted substantially after QE1, banks with MBS holdings above the median 
expanded their lending by around $1.5 \%$ relative to the control group, and keeping the borrower fixed. Columns (2), (4) and (6) show these results to also hold when using the loan renewal dummy as an outcome variable.

Even though C\&I lending accounts for a relatively small portion of total bank credit, this firm-level evidence suggests the bank-level effect of QE documented in the previous section is not due to differential shocks to borrower quality or demand that are synchronous with the interventions.

\subsection{Placebo Tests}

The analysis throughout this paper has addressed the concern of a non-random allocation of MBS by controlling for pertinent observable differences across banks and allowing for a heterogeneous response to the Fed's large-scale asset purchases. This section goes one step further and presents evidence against yet another alternative hypothesis: the worry is simply that commercial banks with relatively large MBS-holdings expand their lending more aggressively during economic recoveries. This might be particularly relevant to the period around QE3, when the US economy was clearly gaining momentum. It is important to rule out that the patterns unveiled in the above figures and regressions were being driven by a heterogeneous reaction among banks to the macroeconomic upturn.

To address this issue, the next placebo tests apply the same exact experiment as in section 4.2., but with a sample running from 2001 through 2004 using quarterly data. Shortly after the NASDAQ crash and following the collapse of the dot-com bubble, the US was in a recession during most of 2001, with the official ending date being 2001Q4. This allows to use $2002 Q 1$ as a placebo LSAP date to investigate what happens to sub- 
sequent lending for the high and low MBS-holding groups of banks. Applying the same matching procedure, re-defining the Treat $t_{i}$ indicator as equal to 1 if a bank belongs to the upper quartile of the MBS-to-Assets distribution in 2001Q1, and estimating specification 2 with all the relevant control variables yields the coefficient plots for the main parameters of interest, $\delta_{t}$, in Figure $6 .{ }^{20}$

[Insert Figure 6 here]

Panels (a)-(c) of Figure 6 reveal there was no differential effect on either total, real estate, or C\&I lending during the macroeconomic upswing following 2001. These placebo tests allow to go a long way in ruling out omitted variable biases pertaining to aggregate factors, and they are consistent with the main interpretation of the findings presented before. There is no evidence to suggest that any of the main results are simply picking up differences in how high MBS-holding banks structure their lending throughout the cycle. Rather, all of the effects seem to be driven by varying exposure towards the Fed's intervention among lending institutions. ${ }^{21}$

\section{Mechanisms}

This section tries to explore the channels behind the effects of QE on bank lending documented in the previous section. Broadly speaking, large-scale asset purchases by the Fed can stimulate lending via balance sheet improvements at banks holding the

\footnotetext{
${ }^{20}$ Leaving the treatment indicator unchanged at the 2008Q1 classification yields almost identical results as, in fact, there is an $84 \%$ overlap between banks considered as belonging to the treatment group at both points in time using the upper quartile definition. This is hardly surprising given how sticky the treatment allocations are found to be in Table 1.

${ }^{21}$ Alternatively, one could have started by just looking at the evolution of relative lending-to-assets for both treated and control banks around the relevant period in 2001-2004, as in Figure 3. These plots end up showing very similar results, with relative lending-to-assets actually declining slightly for treated banks as opposed to the control group. For brevity, only the regression results are presented here.
} 
particular assets being targeted.

The first channel by which QE can improve balance sheets is the "net worth channel". When asset purchases have a large impact on security prices, the policy increases the value of bank security holdings, in turn increasing the mark-to-market value of bank equity. And given that commercial banks target constant leverage ratios (Adrian and Shin (2010b)), this increase in net worth would induce banks to expand their lending and take on additional debt. This mechanism has also been labeled "stealth recapitalization" by Brunnermeier and Sannikov (2014).

The data seems to support the idea of this net worth channel being at play during QE1, but not during the following waves of QE. Figure 7 displays the growth of bank net worth (mark-to-market equity) for the treatment and control groups over the entire period of under consideration. The figure shows a striking increase in the net worth of banks holding relatively more MBS following QE1. On the other hand, there is virtually no difference between the two groups around both QE2 and QE3.

[Insert Figure 7 here]

Why is the net worth channel restricted to QE1? While the implementation of QE1 led to a significant jump in the value of MBS, both QE2 and QE3 had a much more muted effect on these prices. ${ }^{22}$ Moreover, any price effect on Treasuries from QE2 is unlikely to lead to significant balance sheet improvement, as Treasuries holdings are such a small fraction of banking assets.

Two other pieces of evidence lend additional support to the net worth channel being uniquely associated with QE1. Firstly, only QE1 was linked to an expansion of the

\footnotetext{
${ }^{22}$ Note this observation is different from asking what would have the been the counterfactual price absent the intervention. To detect the mechanism empirically, there must have been an actual price change.
} 
treated banks' balance sheet. A necessary condition for the net worth channel to be at play is an increase in total assets following a rise in the value of securities. To empirically test this prediction, Table 8 presents results for difference-in-differences regressions that are identical to the pooled equations in the previous section, except for new dependent variables that are relevant to the mechanisms. ${ }^{23}$ Columns (1) and (2) display the results for the natural logarithm of assets as the dependent variable using both the discrete and continuous treatment allocations, where the coefficients for the continuous measure are standardized for ease of interpretation. Strikingly, the treatment effects are positive and highly significant for QE1, and insignificant for the other two waves.

[Insert Table 8 here]

The second piece of evidence relates to gains on securities. The net worth channel operates by increasing the value of securities holdings, independently of whether these securities are actually sold (realized gains) or kept on the books (unrealized gains). Figure 8 plots the effect of QE1 and QE3 on these gains (or losses) for the treatment and control groups. Panels (a) and (b) show that following QE1, the treated group experienced a significant relative increase in its gains on securities, both realized and unrealized. However, panels (c) and (d) reveal that no such differences exist after QE3. ${ }^{24}$ Columns (3) and (4) of Table 8 robustly confirm this finding in a pooled regression framework across all three waves of QE. The large, positive and significant coefficients in the first

\footnotetext{
${ }^{23}$ Note: whenever $\log \left(\right.$ Assets $\left._{i t}\right)$ is used as the outcome variable, one of the regressors is taken to be $\log \left(\right.$ Assets $\left._{i, 2008 \mathrm{Q} 1}\right)$ interacted with the relevant QE indicator. All other controls remain unaltered.

${ }^{24}$ Moreover, somewhere around the announcement of tapering in early 2013, when all MBS prices collapsed precipitously, both groups of banks seem to record some unrealized losses on their MBS holdings. In analogous but unreported graphs for QE2 we find absolutely no signs of a differential impact on realized or unrealized gains for the treatment and control groups. Again, this is consistent with QE working through a narrow channel and only affecting the particular assets being targeted. Since commercial bank holding companies hold very little Treasuries, the absence of any notable effects is not surprising.
} 
and fourth rows suggest that the net worth channel was unique to QE1.

\section{[Insert Figure 8 here]}

The channel behind the increase in lending following QE3 is different. Another way by which $\mathrm{QE}$ can improve balance sheets is through increasing bank liquidity via acquisitions of MBS directly from these banks, even without large price effects. More precisely, such a "liquidity channel" works through a reallocation on the asset side of banks' balance sheets. As MBS become more liquid, banks can swap them for reserves and expand lending while keeping their total assets fixed. The additional balance sheet illiquidity coming from more lending is mitigated by the extra liquidity on the rest of the asset side. The key difference between this channel and more traditional transmission mechanisms is that balance sheets do not expand, and the increase in lending occurs through a reallocation on the asset side.

The results in Table 8 support this interpretation. Columns (2) and (3) show a positive and significant treatment effect on non-interest bearing reserves after QE3, but not following the previous large-scale asset purchase rounds. In other words, treated banks experience an increase in cash relative to the control group only after QE3. Together with the absence of a relative asset expansion or any substantial gains on securities, this evidence is indicative of QE3 operating through a liquidity mechanism as opposed to a net worth channel. On the other hand, the liquidity channel is unlikely to exist for QE2 as Treasuries are extremely liquid even in the absence of any interventions by the Fed, a notion reinforced by the results in Table $8 .{ }^{25}$

The key message of this section is that large-scale asset purchases can stimulate bank

\footnotetext{
${ }^{25}$ In principle, this channel can also be at play during QE1. The fact that we find no evidence for it can suggest that it was either dwarfed by the net worth channel, or that market conditions were too bad for banks to react very strongly to it.
} 
lending through more than one channel. In particular, although QE1 and QE3 had roughly similar effects on bank lending, they operated through vastly different mechanisms that depended on the joint response of security prices and market conditions. Future work could make use of higher frequency data to shed more light on how overall liquidity created by QE is subsequently used and spread through the banking sector.

\section{Conclusion}

This paper started out by documenting large cross-sectional heterogeneities in commercial banks' mortgage-backed securities holdings and their relative exposure to large-scale asset purchases. The average MBS-to-Assets ratio is $8 \%$ and the standard deviation is about $10 \%$ in a sample that consists of quarterly data on US commercial banks from 2008Q1 until 2014Q1, aggregated to the bank holding company level but excluding any non-bank subsidiaries.

The analysis shows that banks with a relatively large fraction of MBS on their balance sheet expand lending more aggressively after QE1 and QE3 when the Fed targeted those particular types of securities. Within-firm loan-level regressions further demonstrate that the results are not driven by any simultaneous demand-side shocks. The channels tend to vary depending on the magnitude of the price impact following each intervention, with substantial evidence pointing toward a "net-worth channel" around QE1 and a “liquidity mechanism" after QE3.

Contrary to conventional wisdom, these results suggest that $\mathrm{QE}$ had a differential effect on various types of financial institutions in the economy rather than "raising the tide and lifting all boats" for everyone equally via general equilibrium effects. Hence 
the distribution of MBS holdings across agents is crucial to the understanding of the redistributive effects and the exact transmission mechanisms of unconventional monetary policy. This paper is the first to provide direct empirical support for the importance of targeting specific assets rather than just quantity during any large-scale asset purchasing. 


\section{A Appendix: Variable Definitions}

Banks are indexed with $i$, whereas $t$ stands for the quarter. All mortgage-backed securities price series are sourced from Bloomberg. All bank-level variables are drawn from the Consolidated Reports of Condition and Income (FFIEC 031 and FFIEC 041 files). Note that flow variables taken from the income statement of the Call Reports are reported each quarter as "year-to-date". To transform a year-to-date variable into a quarterly one, the variable is taken as listed for the first quarter of each year, and for each subsequent quarter, $Q=\{2,3,4\}$, the variable is calculated as the difference between the year-to-date values between $Q$ and $Q-1$.

- $\left(\frac{\text { MBS }}{\text { Asset }}\right)_{i, t}$ : [held-to-maturity amortized cost mortgage-backed securities + availablefor-sale fair value mortgage-backed securities]/ Assets $_{i, t}$

- $\left(\frac{\text { TRE }}{\text { Asset }}\right)_{\mathrm{i}, \mathrm{t}}:$ [held-to-maturity amortized cost US Treasuries + available-for-sale fair value US Treasuries]/ Assets $_{i, t}$

- Size $_{\mathbf{i}, t}: \log \left(\right.$ Assets $\left._{i, t}\right)$, where Assets $=$ RCFD2170 for banks with foreign offices; $=$ RCON2170 for banks w/o foreign offices.

- Equity $_{\mathbf{i}, \mathrm{t}}$ : 1-Liabilities/Assets, where Liabilities $=$ RCFD2948 and Assets $=$ RCFD2170 for banks with foreign offices, and $=$ RCON2948 and $=$ RCON2170 for banks w/o foreign offices.

- Lending $\mathrm{i}_{\mathrm{i}, \mathrm{t}}$ : loans and leases, net of unearned income $=R C F D 2122$ for banks with foreign offices, and $=$ RCON2122 for banks w/o foreign offices.

- $\mathbf{R E}$ Lending $_{\mathrm{i}, \mathrm{t}}$ : loans secured by real estate $=R C F D 1410$ for banks with foreign 
offices, and sum of RCONF158, RCONF159, RCON1420, RCON1797, RCON5367, RCONF5368, RCON1460, RCONF160, and RCONF161 for banks w/o foreign offices.

- C\&I Lending $\mathrm{i}_{\mathrm{i}, \mathrm{t}}$ : commercial and industrial loans $=$ sum of RCFD1763 and RCFD1764 for banks with foreign offices, and RCON1766 for banks w/o foreign offices.

- Reserves $s_{i, t}$ : cash and balances due from depository institutions = sum of RCFD0081 and RCFD0071 for banks with foreign offices, and sum of RCON0081 and RCON0071 for banks w/o foreign offices.

- Currency $_{\mathbf{i}, \mathrm{t}}$ : non-interest-bearing balances and currency and coin $=R C F D 0081$ for banks with foreign offices, and $=$ RCON0081 for banks w/o foreign offices.

- Net Income $\mathbf{i , t}$ : net income (loss) attributable to bank $=$ RIAD4340. This variable has to be converted from year-to-date to quarterly as explained above.

- $\mathbf{R O A}_{\mathbf{i}, t}:=$ Net Income $_{i, t} /$ Assets $_{i, t}$

- Realised Gains $\mathbf{i}_{\mathbf{i}, \mathbf{t}}$ : realized gains (losses) on held-to-maturity securities [RIAD3521] + realized gains (losses) on available-for-sale securities [RIAD3196]. NB: RIAD3521 and RIAD3196 are transformed from year-to-date to quarterly as explained above.

- Unrealised Gains $s_{i, t}$ : net unrealized gains (losses) on available-for-sale securities, = RCFD8434 for banks w. foreign offices; $=$ RCON8434 for banks w/o foreign offices.

- $\mathrm{Gap}_{\mathrm{i}, \mathrm{t}}$ : duration gap = average repricing/maturity gap between a bank's assets and liabilities at the end of quarter $Q$. 


\section{References}

Adrian, Tobias and Hyun Song Shin, "Chapter 12 - Financial Intermediaries and Monetary Economics," in Benjamin M. Friedman and Michael Woodford, eds., , Vol. 3 of Handbook of Monetary Economics, Elsevier, 2010, pp. 601 - 650.

_ and _ , "Liquidity and leverage," Journal of financial intermediation, 2010, 19 (3), 418-437.

Agarwal, Sumit, Gene Amromin, Souphala Chomsisengphet, Tomasz Piskorski, Amit Seru, and Vincent Yao, “Mortgage Refinancing, Consumer Spending, and Competition: Evidence from the Home Affordable Refinancing Program," 2015. Working Paper.

Beraja, Martin, Andreas Fuster, Erik Hurst, and Joseph Vavra, "Regional Heterogeneity and Monetary Policy," 2016. Working Paper.

Bernanke, Ben and Mark Gertler, "Agency Costs, Net Worth, and Business Fluctuations," The American Economic Review, 1989, pp. 14-31.

_ , , , and Simon Gilchrist, "The financial accelerator in a quantitative business cycle framework," Handbook of macroeconomics, 1999, 1, 1341-1393.

Bianchi, Javier and Saki Bigio, "Banks, liquidity management and monetary policy," 2014. Working Paper.

Borio, Claudio and Haibin Zhu, "Capital regulation, risk-taking and monetary policy: a missing link in the transmission mechanism?," Journal of Financial Stability, 2012, 8 (4), 236-251.

Brunnermeier, Markus K. and Yuliy Sannikov, "A macroeconomic model with a financial sector," The American Economic Review, 2014, 104 (2), 379-421.

_ and _ , "The I-Theory of Money," 2015. Working Paper. 
Campello, Murillo, “Internal capital markets in financial conglomerates: Evidence from small bank responses to monetary policy," The Journal of Finance, 2002, 57 (6), 2773-2805.

Chakraborty, Indraneel, Itay Goldstein, and Andrew MacKinlay, “Monetary Stimulus and Bank Lending," 2016. Working Paper.

Chodorow-Reich, Gabriel, "Effects of Unconventional Monetary Policy on Financial Institutions," in "Brookings Panel on Economic Activity Conference Draft" 2014.

— , "The employment effects of credit market disruptions: Firm-level evidence from the 2008-9 financial crisis," The Quarterly Journal of Economics, 2014, 129 (1), 1-59.

Cornett, Marcia Millon, Jamie John McNutt, Philip E Strahan, and Hassan Tehranian, “Liquidity risk management and credit supply in the financial crisis," Journal of Financial Economics, 2011, 101 (2), 297-312.

Dagher, Jihad and Kazim Kazimov, "Banks' liability structure and mortgage lending during the financial crisis," Journal of Financial Economics, 2015, 116 (3), 565-582.

English, William B, Skander J Van den Heuvel, and Egon Zakrajšek, “Interest Rate Risk and Bank Equity Valuations," 2014. Working Paper.

Erel, Isil, Taylor Nadauld, and René M Stulz, “Why Did Holdings of Highly Rated Securitization Tranches Differ So Much across Banks?," Review of Financial Studies, 2013.

Gambacorta, Leonardo and Paolo Emilio Mistrulli, “Does bank capital affect lending behavior?," Journal of Financial intermediation, 2004, 13 (4), 436-457.

Granger, Clive, "Investigating Causal Relation by Econometric and Cross-Sectional Method," Econometrica, 1969, pp. 424-438. 
Greenstone, Michael, Alexandre Mas, and Hoai-Luu Nguyen, "Do credit market shocks affect the real economy? Quasi-experimental evidence from the Great Recession and 'normal' economic times," 2014. Working Paper.

He, Zhiguo and Arvind Krishnamurthy, "Intermediary Asset Pricing," The American Economic Review, 2013, 103 (2), 732-70.

Ivashina, Victoria and David Scharfstein, "Bank lending during the financial crisis of 2008," Journal of Financial economics, 2010, 97 (3), 319-338.

Jiménez, Gabriel, Atif Mian, José-Luis Peydró, and Jésus Saurina, “The Real Effects of the Bank Lending Channel," 2014. Working Paper.

Kashyap, Anil K and Jeremy C Stein, "Monetary policy and bank lending," in "Monetary policy," The University of Chicago Press, 1994, pp. 221-261.

_ and _, "The impact of monetary policy on bank balance sheets," in "Carnegie-Rochester Conference Series on Public Policy," Vol. 42 Elsevier 1995, pp. 151-195.

_ and _ , "What do a million observations on banks say about the transmission of monetary policy?," The American Economic Review, 2000, pp. 407-428.

_, Raghuram Rajan, and Jeremy C Stein, "Banks as liquidity providers: An explanation for the coexistence of lending and deposit-taking," The Journal of Finance, 2002, 57 (1), 33-73.

Khwaja, Asim Ijaz and Atif Mian, "Tracing the impact of bank liquidity shocks: Evidence from an emerging market," The American Economic Review, 2008, pp. 1413-1442.

Kishan, Ruby P and Timothy P Opiela, "Bank size, bank capital, and the bank lending channel," Journal of Money, Credit and Banking, 2000, pp. 121-141.

Kiyotaki, Nobuhiro and John Moore, “Credit cycles," Journal of Political Economy, 1997, 105 (2). 
Krishnamurthy, Arvind and A Vissing-Jorgensen, "The Ins and Outs of Large Scale Asset Purchases," in "Kansas City Federal Reserve Symposium on Global Dimensions of Unconventional Monetary Policy" 2013.

Landier, Augustin, David Sraer, and David Thesmar, "Banks' Exposure to Interest Rate Risk and The Transmission of Monetary Policy," 2015. Working Paper.

Maggio, Marco Di, Amir Kermani, and Christopher Palmer, “Unconventional Monetary Policy and the Allocation of Credit," 2016. Working Paper.

Morais, Bernardo, José-Luis Peydró, and Claudia Ruiz, “The International Bank Lending Channel of Monetary Policy Rates and Quantitative Easing," 2015. Working Paper.

Paravisini, Daniel, "Local bank financial constraints and firm access to external finance," The Journal of Finance, 2008, 63 (5), 2161-2193.

Peek, Joe and Eric S Rosengren, "Collateral damage: Effects of the Japanese bank crisis on real activity in the United States," The American Economic Review, 2000, pp. 30-45.

Puri, Manju, Jörg Rocholl, and Sascha Steffen, "Global retail lending in the aftermath of the US financial crisis: Distinguishing between supply and demand effects," Journal of Financial Economics, 2011, 100 (3), 556-578.

Shleifer, Andrei and Robert Vishny, "Fire Sales in Finance and Macroeconomics," Journal of Economic Perspectives, 2011, 25 (1), 29-48. 
Figure 1: MBS Prices

(a) Fannie 30-year 3\% Coupon

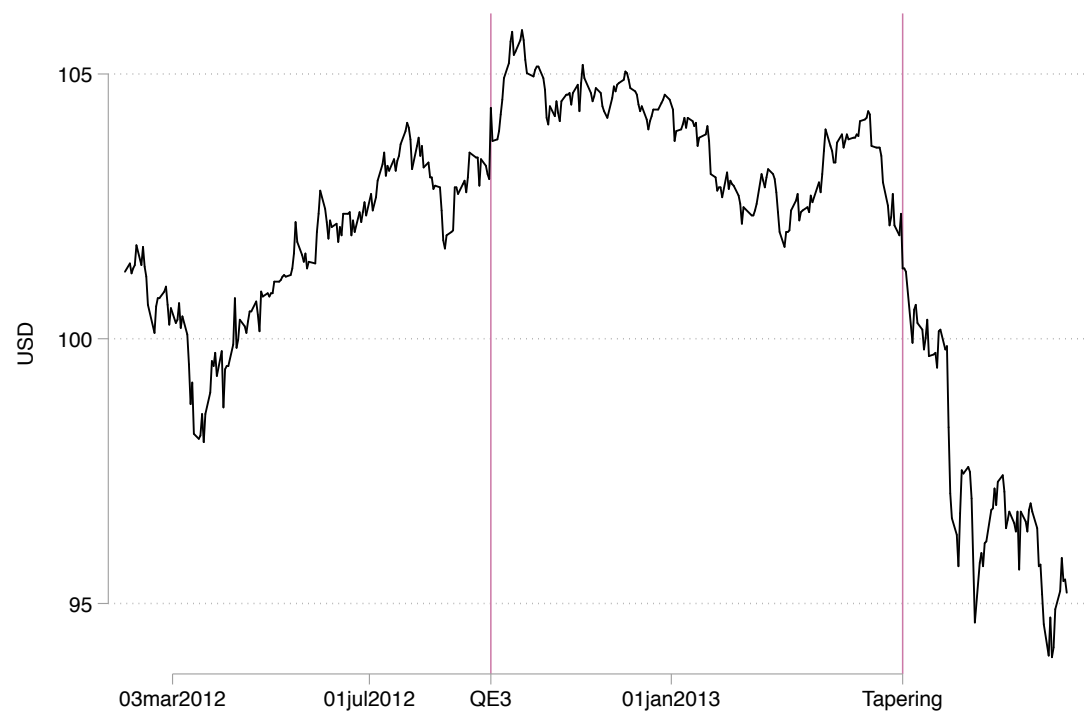

(b) Fannie 30-year 5\% Coupon

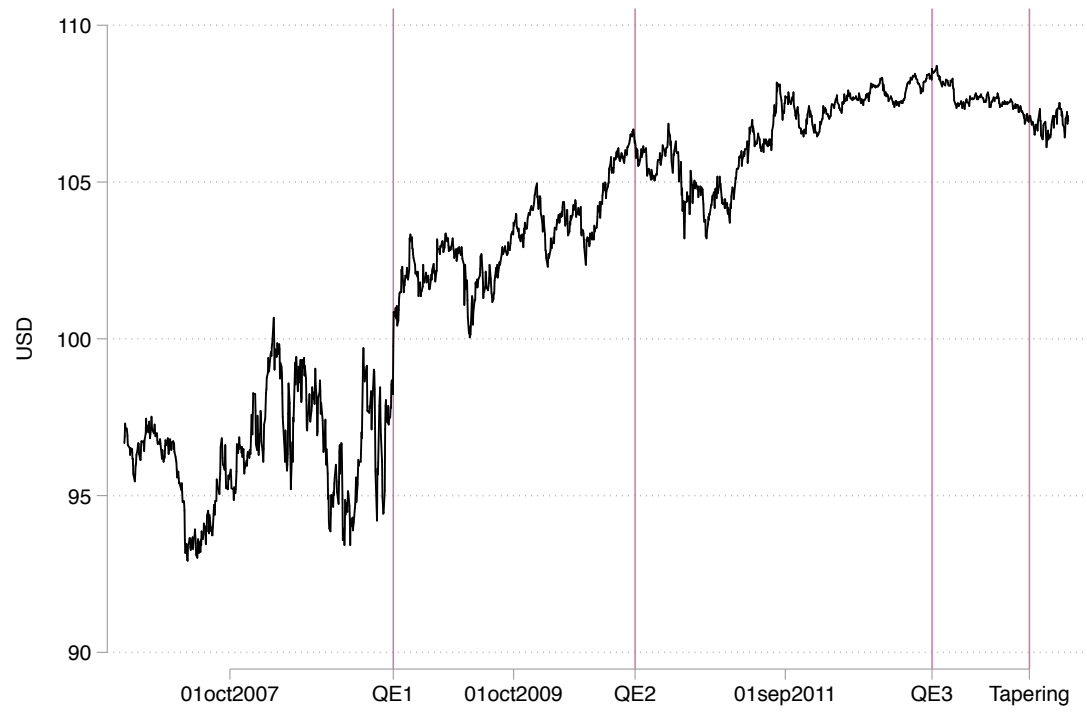

Note: Panel (a) shows the Fannie 30-year 3\% Coupon MBS price series; Panel (b) displays the Fannie 30-year 5\% Coupon MBS price graph. Events related to $Q E 1, Q E 2$, and $Q E 3$ are delineated by vertical red lines. 


\section{Table 1: Transition matrices}

Treatment by quartiles

\begin{tabular}{l|c|c|}
\multicolumn{1}{c}{} & \multicolumn{1}{c}{$T_{i}=0$} & \multicolumn{1}{c}{$T_{i}=1$} \\
\cline { 3 - 3 }$T_{i}=0$ & 99.82 & 0.18 \\
\cline { 3 - 3 }$T_{i}=1$ & 0.19 & 99.81 \\
\cline { 2 - 3 } & &
\end{tabular}

Treatment by median

\begin{tabular}{l|c|c|}
\multicolumn{1}{c}{} & \multicolumn{1}{c}{$T_{i}=0$} & $T_{i}=1$ \\
\cline { 2 - 3 }$T_{i}=0$ & 96 & 4 \\
\cline { 2 - 3 }$T_{i}=1$ & 4 & 96 \\
\cline { 2 - 3 } & &
\end{tabular}

Note: These tables contain transition probabilities for being classified as belonging to the treatment group (defined either by the upper quartile or above the median MBS-to-Assets holdings) between 2008Q1 and 2014Q1.

\section{Figure 2: Cross-Sectional Variation in MBS Holdings}

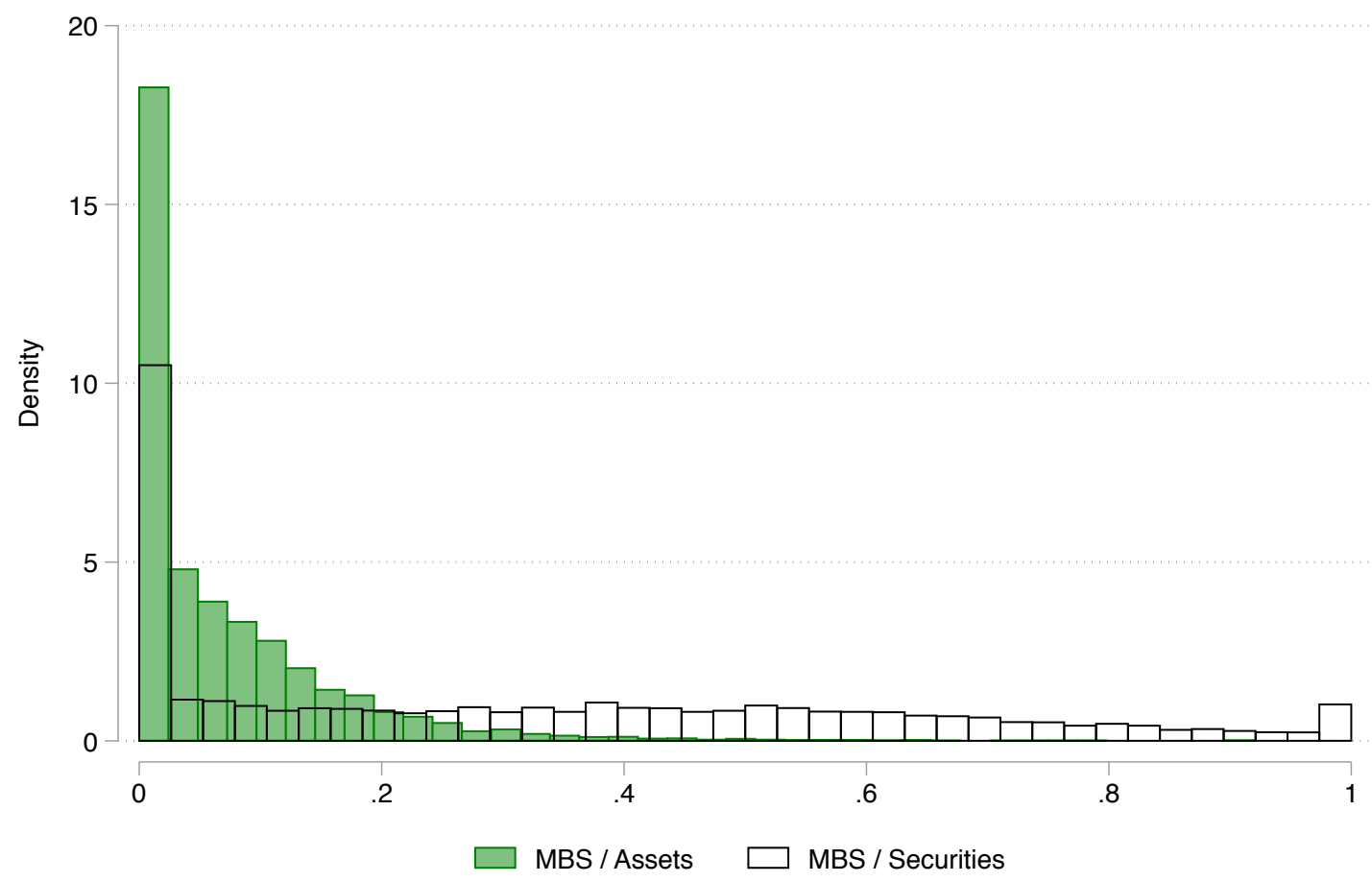

Note: This figure shows a snapshot of the cross-sectional variation in MBS holdings among banks in the main sample. The histogram plots densities for the main treatment variable, the MBS-toAssets ratio as of 2008Q1. For reference, the MBS-to-Securities ratio in this period is also included. 
Figure 3: Quantitative Easing \& Bank Lending

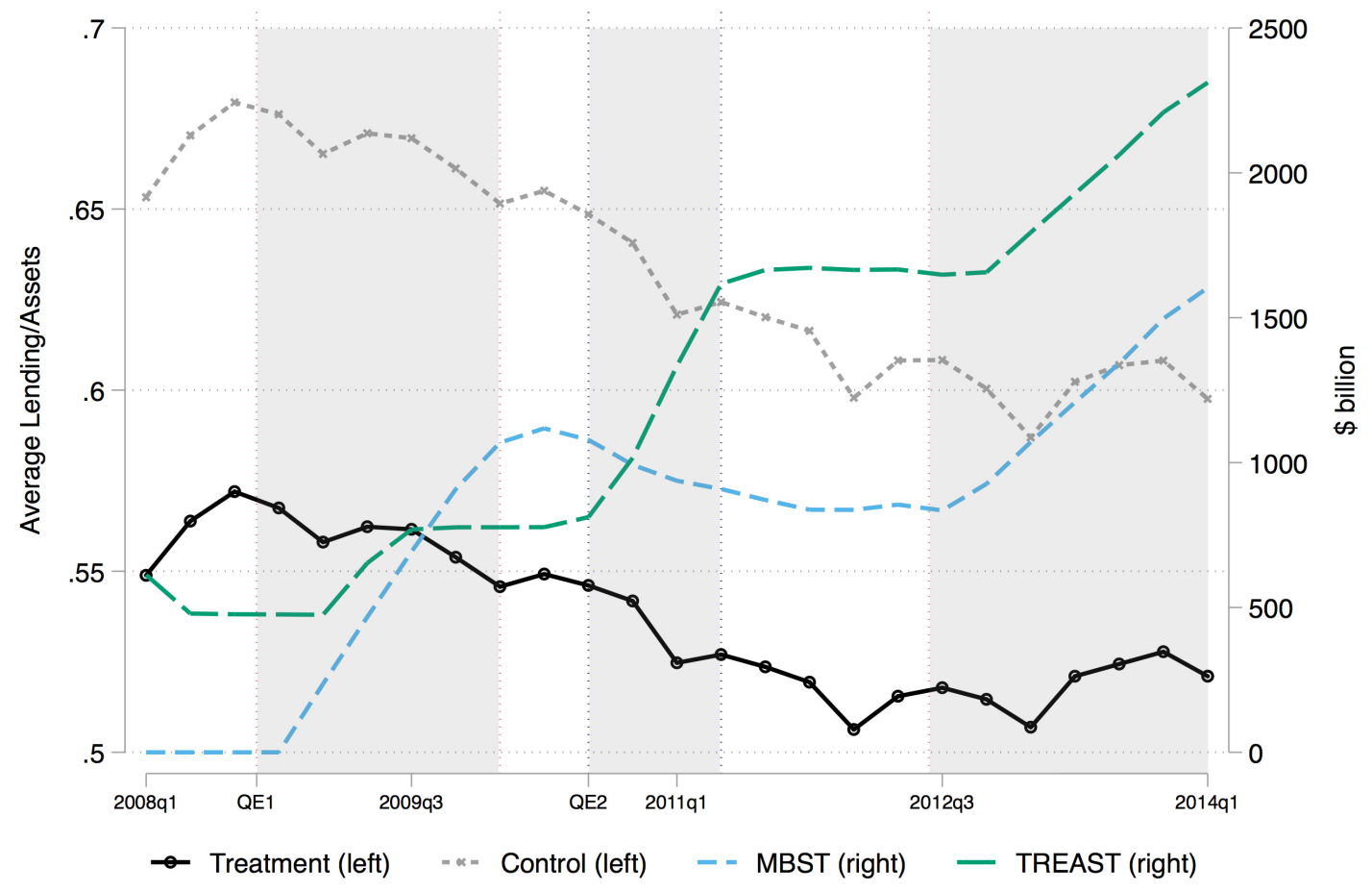

Note: This figure displays the Federal Reserve Holdings of U.S. Treasuries and Mortgage-Backed Securities from 2008Q1 until 2014Q1, all measured on the left vertical axis in USD millions. It also shows the average lending-to-assets ratios for banks within the highest 25\% of MBS-to-Assets holdings versus the lowest $25 \%$. Lending is measured on the right vertical axis. The vertical dashed lines and shaded areas mark the QE1, QE2 and QE3 periods, respectively. 
Table 2: Summary Statistics (Call Reports)

\begin{tabular}{lrrrrrr}
\hline \hline Variable & mean & sd & p25 & p50 & p75 & count \\
\hline $\log ($ assets) & 12.11 & 1.36 & 11.25 & 11.99 & 12.80 & 160606 \\
equity / assets & 0.12 & 0.07 & 0.09 & 0.10 & 0.12 & 160606 \\
mbs / assets & 0.08 & 0.10 & 0.00 & 0.05 & 0.12 & 160606 \\
mbs / securities & 0.35 & 0.31 & 0.03 & 0.32 & 0.60 & 157299 \\
treasuries / securities & 0.03 & 0.13 & 0.00 & 0.00 & 0.00 & 157299 \\
$\log$ (gap) & 4.10 & 0.55 & 3.77 & 4.10 & 4.44 & 159837 \\
deposits / assets & 0.83 & 0.10 & 0.80 & 0.85 & 0.88 & 160606 \\
reserves / assets & 0.09 & 0.09 & 0.03 & 0.06 & 0.11 & 160606 \\
currency / assets & 0.03 & 0.03 & 0.01 & 0.02 & 0.03 & 160606 \\
total lending / assets & 0.62 & 0.17 & 0.53 & 0.65 & 0.74 & 160606 \\
real estate lending / assets & 0.45 & 0.18 & 0.33 & 0.47 & 0.59 & 160606 \\
C\&I lending / assets & 0.09 & 0.07 & 0.04 & 0.07 & 0.11 & 160606 \\
ROA & 0.00 & 0.13 & 0.00 & 0.00 & 0.00 & 160606 \\
realised gains / assets & 0.00 & 0.00 & 0.00 & 0.00 & 0.00 & 160606 \\
unrealised gains / assets & 0.00 & 0.00 & 0.00 & 0.00 & 0.00 & 160606 \\
\hline \hline
\end{tabular}

Note: Summary statistics are based on the Consolidated Reports of Condition and Income between 2008Q1 - 2014Q1 for all US bank holding companies. All variables are quarterly.

Table 3: Summary Statistics (Dealscan)

\begin{tabular}{|c|c|c|c|c|c|}
\hline \multirow[b]{2}{*}{ Sample } & \multicolumn{2}{|c|}{$\Delta \log ($ lending $)$} & \multicolumn{3}{|c|}{ renewal dummy } \\
\hline & mean & sd & mean & sd & count \\
\hline whole & -7.1 & 8.7 & 0.59 & 0.49 & 3267 \\
\hline median treatment & -5.8 & 8.33 & 0.66 & 0.47 & 2116 \\
\hline quartile treatment & -6.05 & 8.41 & 0.65 & 0.48 & 1328 \\
\hline decile treatment & -6.08 & 8.41 & 0.65 & 0.48 & 703 \\
\hline
\end{tabular}

Note: Summary statistics are based on the Dealscan flow data. 
Table 4: Correlation between Treatment and Initial Characteristics

\begin{tabular}{|c|c|c|c|c|c|c|}
\hline & \multicolumn{2}{|c|}{ (1) } & \multicolumn{2}{|c|}{ (2) } & \multicolumn{2}{|c|}{ (3) } \\
\hline & \multicolumn{2}{|c|}{ Treat $_{i}^{D}$} & \multicolumn{2}{|c|}{ Treat $_{i}^{Q}$} & \multicolumn{2}{|c|}{$\left(\frac{M B S}{\text { Assets }}\right)_{i}$} \\
\hline & coeff & s.e. & coeff & s.e. & coeff & s.e. \\
\hline $\log$ (assets) & $0.081^{* * *}$ & [0.009] & $0.099^{* * *}$ & {$[0.007]$} & $0.0068^{* * *}$ & [0.001] \\
\hline liabilities / assets & -0.016 & [0.233] & -0.049 & {$[0.232]$} & $0.095^{*}$ & [0.038] \\
\hline securities / assets & $1.317^{* * *}$ & [0.127] & $1.596^{* * *}$ & {$[0.114]$} & $0.374^{* * *}$ & [0.021] \\
\hline deposits / assets & 0.216 & [0.191] & 0.209 & [0.192] & -0.049 & [0.031] \\
\hline other borrowing / assets & $1.023^{* * *}$ & {$[0.254]$} & $0.929^{* * *}$ & {$[0.234]$} & $0.166^{* * *}$ & [0.039] \\
\hline reserves / assets & 0.258 & [0.134] & $0.358^{*}$ & {$[0.156]$} & $0.0647^{* *}$ & [0.024] \\
\hline lending / assets & -0.184 & [0.108] & 0.138 & [0.104] & -0.002 & [0.016] \\
\hline realized gains / assets & 22.59 & [19.34] & 41.65 & [21.40] & $0.913^{* * *}$ & [0.200] \\
\hline unrealized gains / assets & -2.833 & [3.013] & -0.961 & [2.958] & $-1.458^{* *}$ & [0.496] \\
\hline duration gap & 0.0009 & [0.001] & 0.0007 & {$[0.000]$} & $0.0001^{* *}$ & [0.000] \\
\hline ROA & $-2.954^{*}$ & [1.168] & $-4.608^{* *}$ & [1.485] & $-1.106^{* * *}$ & [0.289] \\
\hline$N$ & 1594 & & 2588 & & 5148 & \\
\hline $\operatorname{adj} \cdot R^{2}$ & 0.471 & & 0.370 & & 0.380 & \\
\hline
\end{tabular}

Note: This table regresses the treatment status defined by the decile of MBS-to-Assets holdings (column 1), quartile (column 2), and the continuous MBS-to-Assets measure (column 3) on various bank characteristics in 2008Q1, and reports the coefficient and standard errors for each variable. Standard errors are clustered at the bank-level and displayed in brackets. $* * *, * *, *$ indicate significance at the $1 \%, 5 \%$ and $10 \%$ levels, respectively. 


\section{Table 5: Propensity Score Matching}

\begin{tabular}{lcc}
\hline \hline & \multicolumn{2}{c}{ Treat $_{i}$} \\
\cline { 2 - 3 } & $(1)$ & $(2)$ \\
\hline \multirow{2}{*}{ Size } & $0.211^{* * *}$ & -0.004 \\
& {$[0.015]$} & {$[0.024]$} \\
Equity & 0.107 & -0.271 \\
& {$[0.212]$} & {$[0.306]$} \\
ROA & $-3.802^{*}$ & -6.071 \\
& {$[2.256]$} & {$[4.559]$} \\
Constant & $-2.509^{* * *}$ & 0.090 \\
& {$[0.185]$} & {$[0.294]$} \\
& & \\
Matching & pre- & post- \\
Observations & 5,152 & 5,186 \\
$p$-value & 0.00 & 0.509 \\
\hline
\end{tabular}

Note: This table presents coefficient estimates from probit regressions used in estimating the propensity scores for the treatment and control group of banks in 2008Q1. The dependent variable is a bank's treatment status; the controls include Size (log total assets), equity over assets, and return on assets (ROA). Column (1) contains estimates using the entire sample prior to matching; this model generates the propensity scores. Column (2) uses the subsample of treated and control banks after matching. Standard errors are in brackets. $* * * * * *$ indicate significance at the $1 \%, 5 \%$ and $10 \%$ levels, respectively. 
Table 6: Pooled QE Regression

\begin{tabular}{|c|c|c|c|c|c|c|}
\hline & \multicolumn{2}{|c|}{$\log \left(\right.$ Lending $\left._{i t}\right)$} & \multicolumn{2}{|c|}{$\log \left(\right.$ RE Lending $\left.{ }_{i t}\right)$} & \multicolumn{2}{|c|}{$\log \left(\right.$ CI Lending L $\left._{i t}\right)$} \\
\hline & (1) & (2) & (3) & (4) & (5) & (6) \\
\hline Treat $_{M, i} \cdot Q E 1_{t}$ & $\begin{array}{c}0.034^{* * *} \\
{[0.008]}\end{array}$ & & $\begin{array}{c}0.047^{* * * *} \\
{[0.009]}\end{array}$ & & $\begin{array}{c}0.004 \\
{[0.028]}\end{array}$ & \\
\hline Treat $_{T, i} \cdot Q E 2_{t}$ & $\begin{array}{l}0.028 \\
{[0.018]}\end{array}$ & & $\begin{array}{l}-0.008 \\
{[0.014]}\end{array}$ & & $\begin{array}{c}0.034 \\
{[0.037]}\end{array}$ & \\
\hline Treat $_{M, i} \cdot Q E 3_{t}$ & $\begin{array}{l}0.017^{* * *} \\
{[0.008]}\end{array}$ & & $\begin{array}{l}0.021 * * \\
{[0.010]}\end{array}$ & & $\begin{array}{c}0.011 \\
{[0.039]}\end{array}$ & \\
\hline$\left(\frac{M B S}{A s s e t}\right)_{i} \cdot Q E 1_{t}$ & & $\begin{array}{c}0.178^{* * * *} \\
{[0.041]}\end{array}$ & & $\begin{array}{l}0.248^{* * *} \\
{[0.046]}\end{array}$ & & $\begin{array}{r}0.146 \\
{[0.093]}\end{array}$ \\
\hline$\left(\frac{T R E}{A s s e t}\right)_{i} \cdot Q E 2_{t}$ & & $\begin{array}{l}0.084 \\
{[0.067]}\end{array}$ & & $\begin{array}{l}0.080 \\
{[0.121]}\end{array}$ & & $\begin{array}{c}0.291 \\
{[0.221]}\end{array}$ \\
\hline$\left(\frac{M B S}{\text { Asset }}\right)_{i} \cdot Q E 3_{t}$ & & $\begin{array}{c}0.172^{* * *} \\
{[0.040]}\end{array}$ & & $\begin{array}{c}0.144^{* * * *} \\
{[0.047]}\end{array}$ & & $\begin{array}{c}0.328^{* * * *} \\
{[0.100]}\end{array}$ \\
\hline $\begin{array}{l}Q E_{t} \\
\text { Controls } \\
\text { Controls } \cdot Q E_{t} \\
\text { Bank FEs }\end{array}$ & $\begin{array}{l}\text { Yes } \\
\text { Yes } \\
\text { Yes } \\
\text { Yes }\end{array}$ & $\begin{array}{l}\text { Yes } \\
\text { Yes } \\
\text { Yes } \\
\text { Yes }\end{array}$ & $\begin{array}{l}\text { Yes } \\
\text { Yes } \\
\text { Yes } \\
\text { Yes }\end{array}$ & $\begin{array}{l}\text { Yes } \\
\text { Yes } \\
\text { Yes } \\
\text { Yes }\end{array}$ & $\begin{array}{l}\text { Yes } \\
\text { Yes } \\
\text { Yes } \\
\text { Yes }\end{array}$ & $\begin{array}{l}\text { Yes } \\
\text { Yes } \\
\text { Yes } \\
\text { Yes }\end{array}$ \\
\hline $\begin{array}{l}\text { Number of banks } \\
\text { Observations } \\
R^{2} \\
p \text {-value }\end{array}$ & $\begin{array}{c}1,939 \\
59,870 \\
0.668 \\
0.0613 \\
\end{array}$ & $\begin{array}{c}3,949 \\
128,966 \\
0.711 \\
0.879 \\
\end{array}$ & $\begin{array}{c}1,934 \\
59,608 \\
0.543 \\
0.0459 \\
\end{array}$ & $\begin{array}{c}3,941 \\
128,390 \\
0.508 \\
0.0345 \\
\end{array}$ & $\begin{array}{c}1,916 \\
58,613 \\
0.219 \\
0.885\end{array}$ & $\begin{array}{c}3,914 \\
127,027 \\
0.239 \\
0.138 \\
\end{array}$ \\
\hline
\end{tabular}

Note: This table presents coefficient estimates from specifications at the BHC level relating lending from 2008Q1 to 2014Q1 with banks' initial exposure towards LSAPs, as captured by their treatment group membership or MBSto-Assets ratio back in 2008Q1. The controls include Size (log total assets), equity over assets, return on assets (ROA), and the duration gap. $Q E_{t}$ denotes the triple of $Q E$ indicators. The reported p-value tests for coefficient inequality between QE1 and QE3. Standard errors [in brackets] are clustered at the bank-level to allow for serial correlation across time. ${ }^{* * *}, * *, *$ indicate significance at the $1 \%, 5 \%$ and $10 \%$ levels, respectively. 


\section{Figure 4: All Banks - coefficients plots}

(a) Total Lending

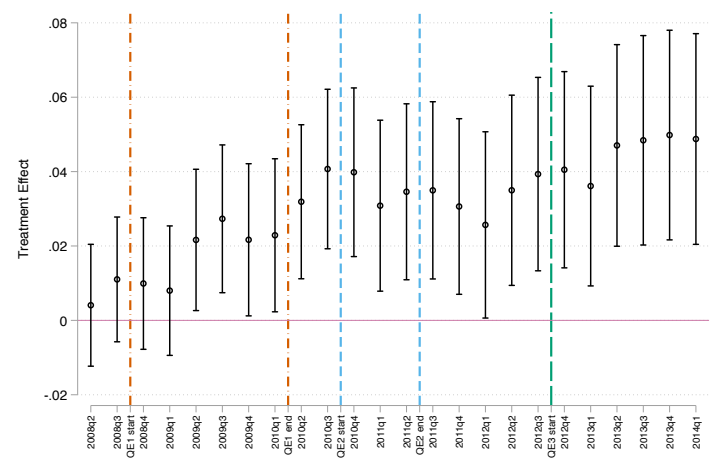

(b) RE Lending

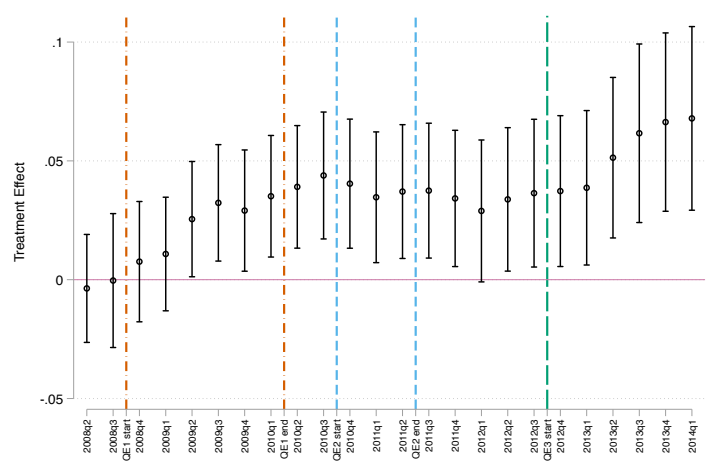

(c) C\&I Lending

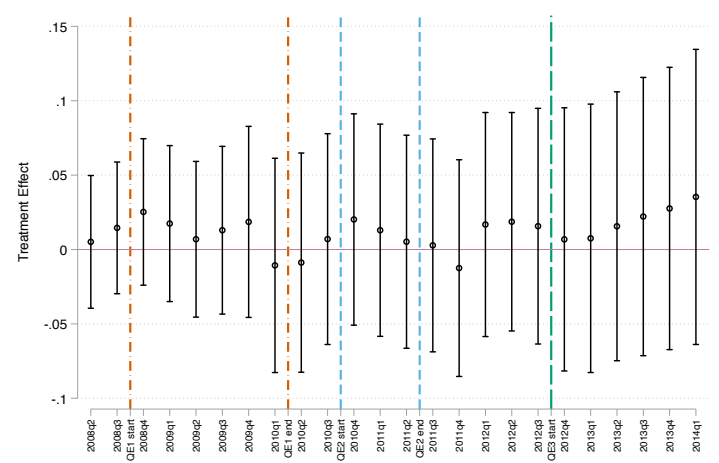

Note: These figures plot the estimated $\delta_{t}$ coefficients of equation 2 with 95\% confidence intervals around them. Time is measured on a quarterly level and the vertical vermillion (dot-dashed), light-blue (dashed) and turquoise (long-dashed) lines mark the QE1, QE2 and QE3 episodes, respectively. 


\section{Figure 5: Small vs. Large Banks - coefficient plots}

(a) Total Lending

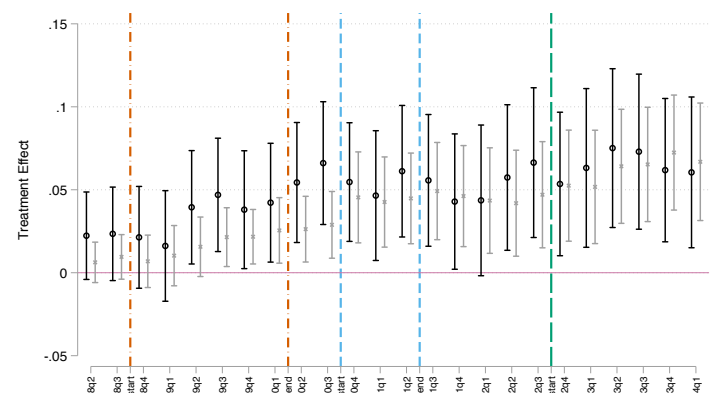

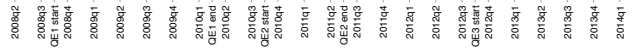

$\circ$ small $\times$ large

(b) RE Lending

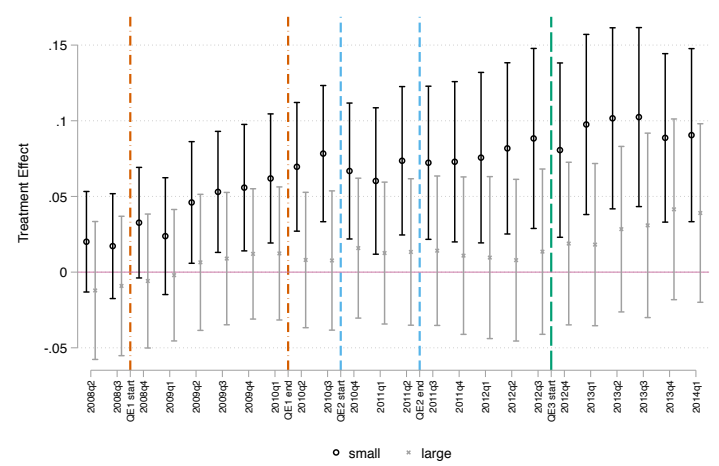

(c) C\&I Lending

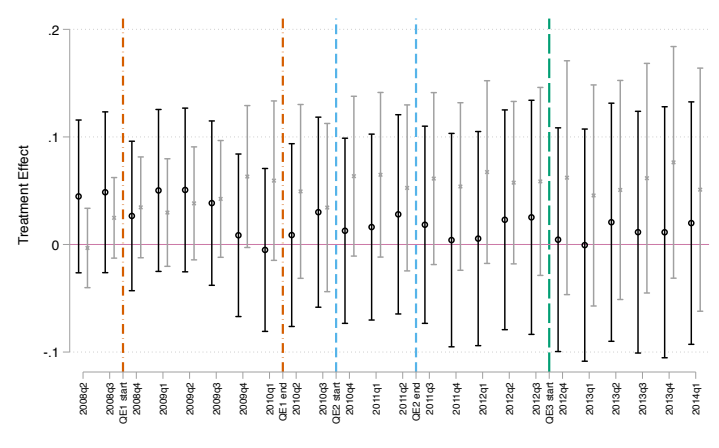

Note: These figures plot the estimated $\delta_{t}$ coefficients of equation 2 for small and large banks with $95 \%$ confidence intervals around them. Time is measured on a quarterly level and the vertical vermillion (dot-dashed), light-blue (dashed) and turquoise (long-dashed) lines mark the QE1, QE2 and QE3 episodes, respectively. 
Table 7: Khwaja-Mian Estimator

\begin{tabular}{|c|c|c|c|c|c|c|}
\hline & \multicolumn{6}{|c|}{ odd: $\Delta \log (\operatorname{loan}) ;$ even: renewal } \\
\hline & \multicolumn{2}{|c|}{ QE1 } & \multicolumn{2}{|c|}{ QE2 } & \multicolumn{2}{|c|}{ QE3 } \\
\hline & $(1)$ & $(2)$ & (3) & (4) & (5) & (6) \\
\hline \multirow[t]{2}{*}{ Treat $_{b}$} & $1.51^{* *}$ & $0.09 * *$ & 0.81 & 0.04 & $2.31 * *$ & $0.13^{* *}$ \\
\hline & {$[0.80]$} & {$[0.04]$} & {$[0.80]$} & {$[0.05]$} & {$[0.77]$} & {$[0.04]$} \\
\hline \multirow[t]{2}{*}{ Constant } & $-12.17^{* * *}$ & $0.31^{* * *}$ & $-7.10^{* * *}$ & $0.59 * * *$ & $-7.99 * * *$ & $0.54^{* * *}$ \\
\hline & {$[0.75]$} & {$[0.04]$} & [0.77] & {$[0.04]$} & {$[0.74]$} & {$[0.04]$} \\
\hline Firm FEs & Yes & Yes & Yes & Yes & Yes & Yes \\
\hline No. of firms & 367 & 367 & 514 & 514 & 674 & 674 \\
\hline Observations & 1384 & 1384 & 1763 & 1763 & 2116 & 2116 \\
\hline$R^{2}$ & 0.01 & 0.01 & 0.00 & 0.00 & 0.01 & 0.01 \\
\hline
\end{tabular}

Note: This table presents coefficient estimates from specifications at the CEI loan-level relating changes in lending to a bank's MBS holding, for each wave of $Q E$. The dependent variable is either i) the log change in the dollar amount of lending by a syndicate member from the pre- to the post-QE period (odd columns), or ii) a loan renewal dummy (even columns). Pre- and post-QE periods are defined as follows for each waves: QE1 (Sept.2005 - Nov. 2008 and Dec. 2008 - Jan. 2010) , QE2 (Sept. 2008 - Nov.r 2010 and Dec. 2010 - Jan. 2012), QE3 (Jul. 2010 - Sept. 2012 and Oct. 2012 - Dec. 2013). Firm fixedeffects are included in columns (1)-(6), and Treat ${ }_{b}$ denotes the MBS treatment indicator, splitting the sample according to median MBS holdings. The sample includes one observation for each lead lender and participant in the pre-QE syndicate. Standard errors are in brackets. ${ }^{* * * * *}, *$ indicate significance at the $1 \%, 5 \%$ and $10 \%$ levels, respectively. 
Figure 6: Placebo tests - coefficients plots

(a) Total Lending

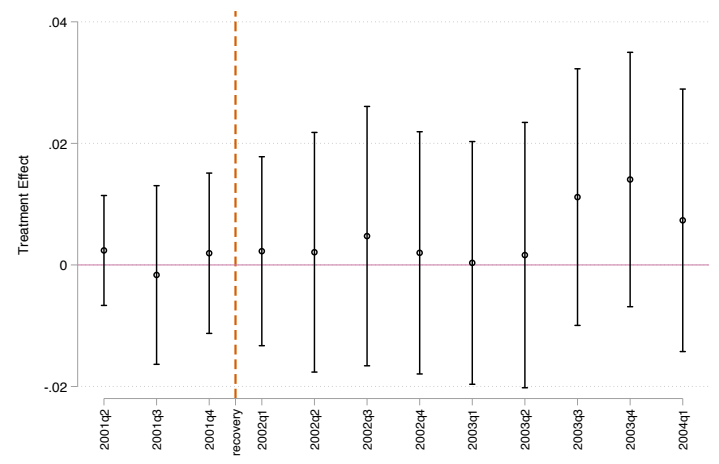

(b) RE Lending

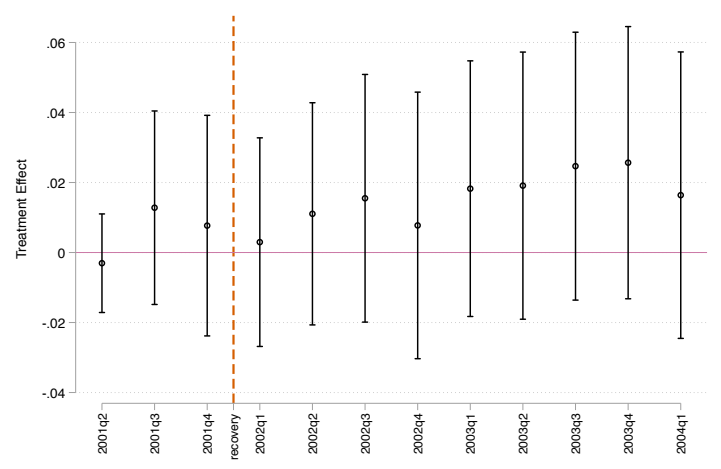

(c) C\&I Lending

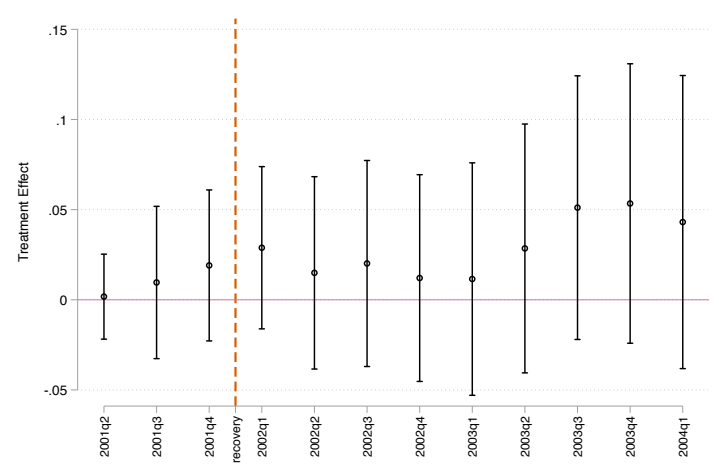

Note: These figures plot the estimated $\delta_{t}$ coefficients of equation 2 with $95 \%$ confidence intervals around them for the period from 2001Q2 to 2004Q4. Time is measured on a quarterly level and the vertical vermillion dashed line marks the beginning of the post-2001 economic boom. 
Figure 7: Mechanisms: Net Worth

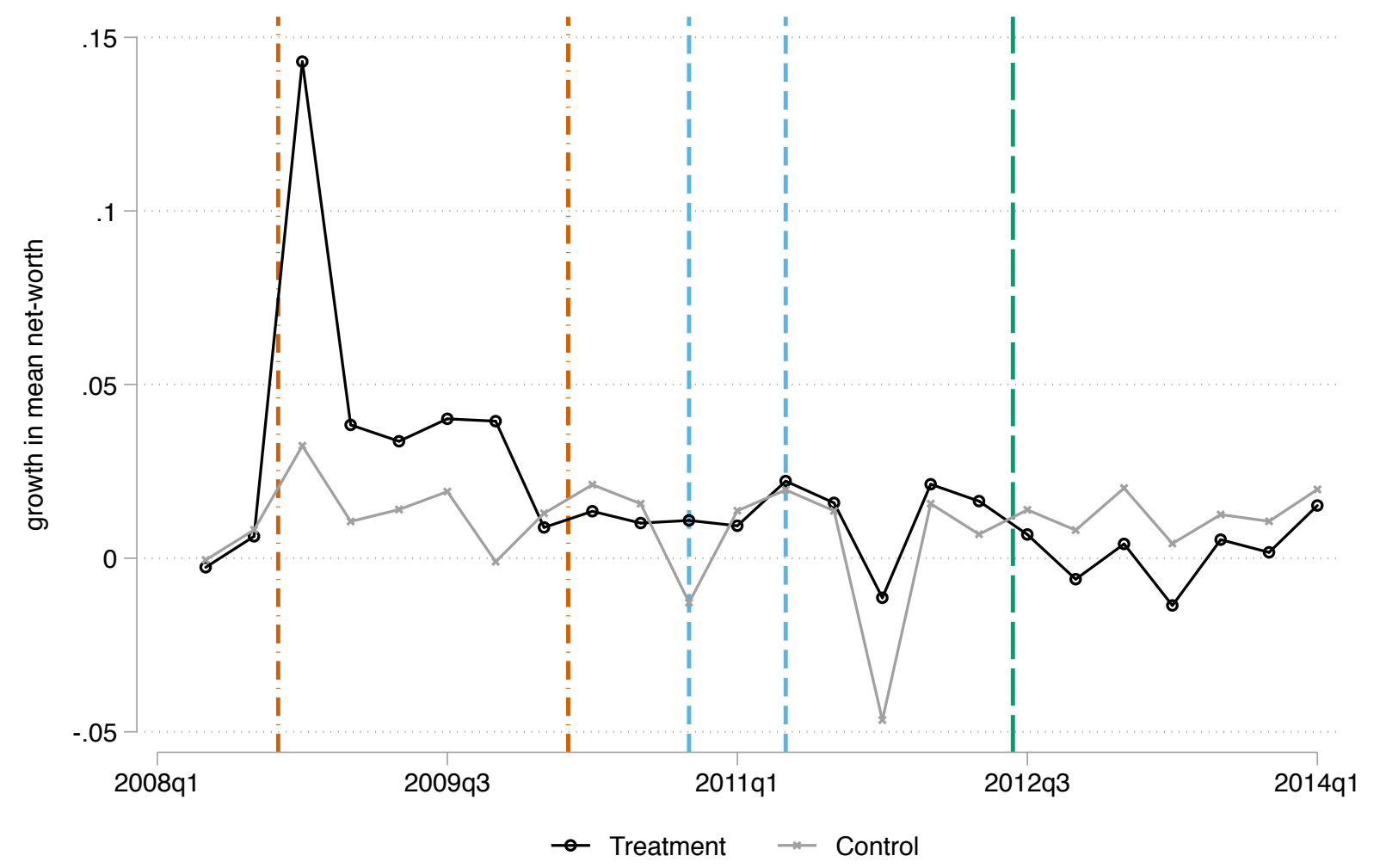

Note: This figure displays the average growth of bank net worth around QE1 (between vertical vermillion dashdotted lines), QE2 (between light-blue dashed lines) and QE3 (right of turquoise vertical long-dashed line). Banks in the treatment group belong to the upper quartile of the MBS-to-Assets distribution in 2008Q1, while banks in the control group belong to the lower quartile. 


\section{Figure 8: Mechanisms: Realized and Unrealized Gains}

(a) QE1: Realized Gains

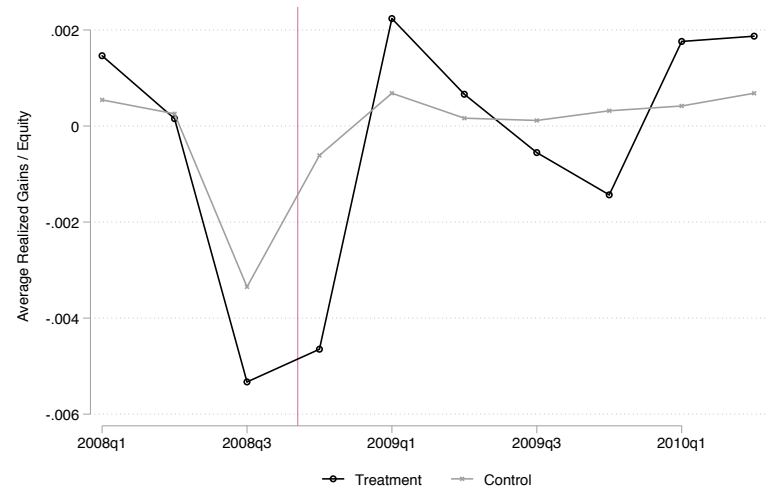

(c) QE3: Realized Gains

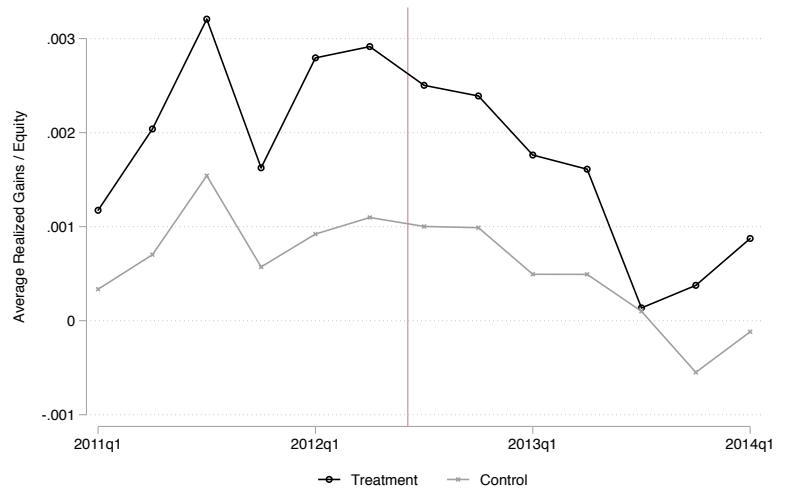

(b) QE1: Unrealized Gains

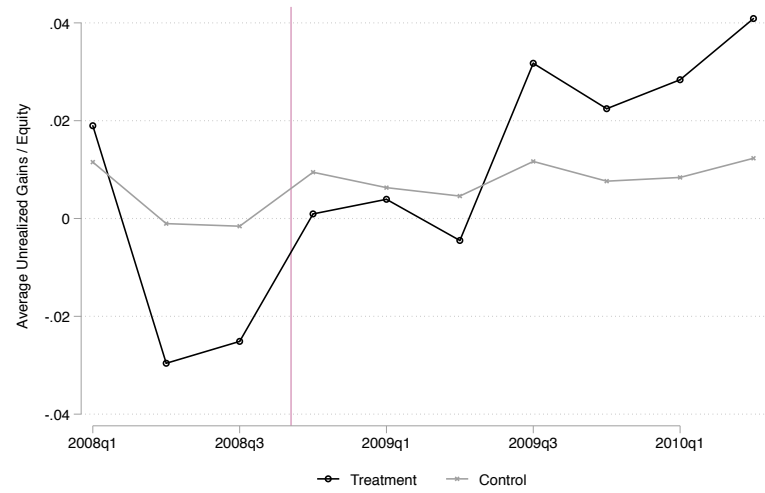

(d) QE3: Unrealized Gains

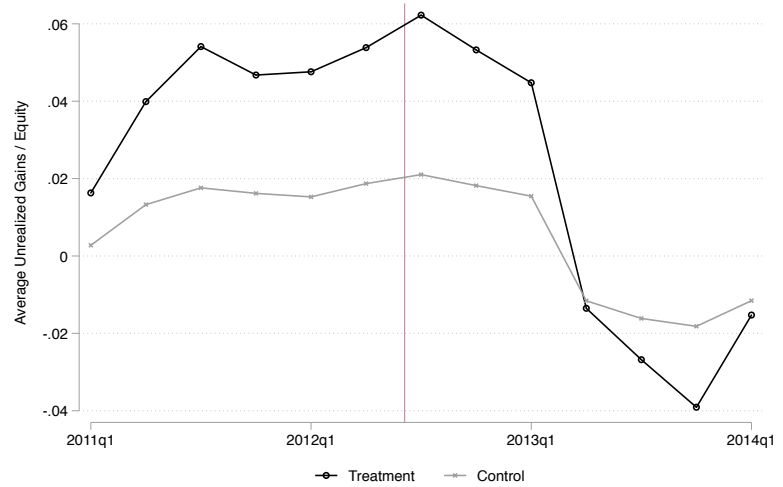

Note: Panels (a) and (b) display the average net realized and unrealized gains (or losses) on securities as a fraction of equity around QE1 (red vertical line), respectively. Panels (c) and (d) plot the corresponding figures around QE3. Banks in the treatment group belong to the upper quartile of the MBS-to-Assets distribution in 2008Q1, while banks in the control group belong to the lower quartile. 
Table 8: Mechanisms

\begin{tabular}{|c|c|c|c|c|c|c|}
\hline & \multicolumn{2}{|c|}{$\log \left(\right.$ Assets $\left._{i t}\right)$} & \multicolumn{2}{|c|}{$\log \left(\right.$ Currency $\left._{i t}\right)$} & \multicolumn{2}{|c|}{$\log \left(\right.$ RGains $\left._{i t}\right)$} \\
\hline & (1) & (2) & (3) & (4) & (5) & (6) \\
\hline Treat $_{M, i} \cdot Q E 1_{t}$ & $\begin{array}{c}0.025^{* * *} \\
{[0.009]}\end{array}$ & & $\begin{array}{l}-0.041 \\
{[0.030]}\end{array}$ & & $\begin{array}{c}0.635^{* * *} \\
{[0.185]}\end{array}$ & \\
\hline Treat $_{T, i} \cdot Q E 2_{t}$ & $\begin{array}{l}0.016 \\
{[0.013]}\end{array}$ & & $\begin{array}{l}0.013 \\
{[0.035]}\end{array}$ & & $\begin{array}{l}-0.036 \\
{[0.119]}\end{array}$ & \\
\hline Treat $_{M, i} \cdot Q E 3_{t}$ & $\begin{array}{l}0.006 \\
{[0.010]}\end{array}$ & & $\begin{array}{l}0.048^{*} \\
{[0.026]}\end{array}$ & & $\begin{array}{l}-0.033 \\
{[0.105]}\end{array}$ & \\
\hline$\left(\frac{M B S}{\text { Asset }}\right)_{i} \cdot Q E 1_{t}$ & & $\begin{array}{c}0.007^{* *} \\
{[0.003]}\end{array}$ & & $\begin{array}{r}-0.006 \\
{[0.010]}\end{array}$ & & $\begin{array}{c}0.180^{* * *} \\
{[0.043]}\end{array}$ \\
\hline$\left(\frac{T R E}{\text { Asset }}\right)_{i} \cdot Q E 2_{t}$ & & $\begin{array}{l}0.000 \\
{[0.003]}\end{array}$ & & $\begin{array}{l}-0.005 \\
{[0.006]}\end{array}$ & & $\begin{array}{l}-0.044 \\
{[0.061]}\end{array}$ \\
\hline$\left(\frac{M B S}{\text { Asset }}\right)_{i} \cdot Q E 3_{t}$ & & $\begin{array}{c}0.001 \\
{[0.002]}\end{array}$ & & $\begin{array}{l}0.008^{*} \\
{[0.004]}\end{array}$ & & $\begin{array}{r}-0.026 \\
{[0.020]}\end{array}$ \\
\hline $\begin{array}{l}Q E_{t} \\
\text { Controls } \\
\text { Controls } \cdot Q E_{t} \\
\text { Bank FEs }\end{array}$ & $\begin{array}{l}\text { Yes } \\
\text { Yes } \\
\text { Yes } \\
\text { Yes }\end{array}$ & $\begin{array}{l}\text { Yes } \\
\text { Yes } \\
\text { Yes } \\
\text { Yes }\end{array}$ & $\begin{array}{l}\text { Yes } \\
\text { Yes } \\
\text { Yes } \\
\text { Yes }\end{array}$ & $\begin{array}{l}\text { Yes } \\
\text { Yes } \\
\text { Yes } \\
\text { Yes }\end{array}$ & $\begin{array}{l}\text { Yes } \\
\text { Yes } \\
\text { Yes } \\
\text { Yes }\end{array}$ & $\begin{array}{l}\text { Yes } \\
\text { Yes } \\
\text { Yes } \\
\text { Yes }\end{array}$ \\
\hline $\begin{array}{l}\text { Number of banks } \\
\text { Observations } \\
R^{2} \\
p \text {-value }\end{array}$ & $\begin{array}{c}1,939 \\
59,870 \\
0.439 \\
0.0500\end{array}$ & $\begin{array}{c}3,949 \\
128,970 \\
0.372 \\
0.0131\end{array}$ & $\begin{array}{c}1,939 \\
59,844 \\
0.104 \\
0.0223\end{array}$ & $\begin{array}{c}3,949 \\
128,928 \\
0.099 \\
0.169\end{array}$ & $\begin{array}{c}1,632 \\
18,624 \\
0.041 \\
0.0027\end{array}$ & $\begin{array}{c}3,457 \\
41,361 \\
0.032 \\
0.0000\end{array}$ \\
\hline
\end{tabular}

Note: This table presents coefficient estimates from specifications at the BHC level relating lending from 2008Q1 to 2014Q1 with banks' initial exposure towards LSAPs, as captured by their treatment group membership or standardized MBS-to-Assets ratio back in 2008Q1. The reported p-value tests for coefficient inequality between QE1 and QE3. Standard errors [in brackets] are clustered at the bank-level to allow for serial correlation across time. $* * *, * *, *$ indicate significance at the $1 \%, 5 \%$ and $10 \%$ levels, respectively. 